medRxiv preprint doi: https://doi.org/10.1101/2022.02.18.22270995; this version posted February 19, 2022. The copyright holder for this preprint (which was not certified by peer review) is the author/funder, who has granted medRxiv a license to display the preprint in

It is made available under a CC-BY-ND 4.0 International license .

\title{
1 Host and microbiome features of secondary infections in lethal covid-19
}

2 Martin Zacharias $^{1 \#}$, Karl Kashofer ${ }^{1 \#}$, Philipp Wurm ${ }^{1 \#}$, Peter Regitnig ${ }^{1}$, Moritz Schütte ${ }^{2}$, Margit

3 Neger $^{1}$, Sandra Ehmann ${ }^{1}$, Leigh M. Marsh ${ }^{3}$, Grazyna Kwapiszewska ${ }^{3}$, Martina Loibner ${ }^{1}$, Anna

4 Birnhuber $^{3}$, Eva Leitner ${ }^{4}$, Andrea Thüringer ${ }^{1}$, Elke Winter ${ }^{1}$, Stefan Sauer ${ }^{1}$, Marion J.

5 Pollheimer ${ }^{1}$, Fotini R. Vagena ${ }^{1}$, Carolin Lackner ${ }^{1}$, Barbara Jelusic ${ }^{1}$, Lesley Ogilvie ${ }^{2}$, Marija

6 Durdevic $^{1}$, Bernd Timmermann ${ }^{5}$, Hans Lehrach ${ }^{2,5}$, Kurt Zatloukal ${ }^{1 *}$, and Gregor Gorkiewicz ${ }^{1 *}$

1 Diagnostic and Research Institute of Pathology, Medical University of Graz, Neue 10 Stiftingtalstrasse 6, A-8010 Graz, Austria

${ }^{2}$ Alacris Theranostics GmbH, Max-Planck-Strasse 3, D-12489 Berlin, Germany

${ }^{3}$ Ludwig Boltzmann Institute for Lung Vascular Research, Neue Stiftingtalstrasse 6/VI, A-8010

13 Graz, Austria

$14{ }^{4}$ Diagnostic and Research Institute of Hygiene, Microbiology and Environmental Medicine,

Medical University of Graz, Neue Stiftingtalstrasse 6, A-8010 Graz, Austria

${ }^{5}$ Max Planck Institute for Molecular Genetics, Ihnestrasse 63, D-14195 Berlin, Germany

"contributed equally

*correspondence:

Gregor Gorkiewicz, MD

Diagnostic and Research Institute for Pathology, Medical University of Graz

Neue Stiftingtalstrasse 6, A-8010 Graz, Austria

Phone: +43-316-385-71743

Email: gregor.gorkiewicz@medunigraz.at

ORCID: 0000-0003-1149-4782

Kurt Zatloukal, MD

Diagnostic and Research Institute for Pathology, Medical University of Graz

Neue Stiftingtalstrasse 6, A-8010 Graz, Austria

29 Phone: +43-316-385-71732

30 Email: kurt.zatloukal@medunigraz.at

ORCID: 0000-0001-5299-7218

Keywords: Covid-19, autopsy, metatranscriptome, lung microbiome, diffuse alveolar damage, 
medRxiv preprint doi: https://doi.org/10.1101/2022.02.18.22270995; this version posted February 19, 2022. The copyright holder for this preprint (which was not certified by peer review) is the author/funder, who has granted medRxiv a license to display the preprint in It is made available under a CC-BY-ND 4.0 International license .

38

39

40

41

42

43

44

45

46

47

48

49

57

58

59

60

\section{Abstract}

Secondary infections contribute significantly to covid-19 mortality but host and microbial factors driving this sequel remain poorly understood. We performed an autopsy study of 20 covid-19 cases and 14 controls from the first pandemic wave. Autopsies combined with microbial cultivation and deep RNA sequencing (RNAseq) allowed us to define major organ pathologies and specify secondary infections. Lethal covid-19 segregated into two main death causes separating cases with either dominant diffuse alveolar damage (DAD) or secondary infections of lungs. Lung microbiome changes were profound in covid-19 showing a reduced biodiversity and increased presence of prototypical bacterial and fungal pathogens in cases with secondary infections. Deep RNAseq of lung tissues distinctly mirrored death causes and cellular deconvolution stratified DAD cases into subgroups with different cellular compositions. Myeloid cells, including macrophages, and complement $\mathrm{C} 1 \mathrm{q}$ activation were found to be strong stratifying factors suggesting a pathophysiological link possibly leading to tolerance in DAD subgroups. Moreover, several signs of immune-impairment were evident in covid-19 lungs including strong induction of inhibitory immune-checkpoints. Thus, our study highlights profound alterations of the local immunity in covid-19, wherein immuneimpairment leads to reduced antimicrobial defense favoring the development of secondary infections on top of SARS-CoV-2 infection. 
medRxiv preprint doi: https://doi.org/10.1101/2022.02.18.22270995; this version posted February 19, 2022. The copyright holder for this preprint (which was not certified by peer review) is the author/funder, who has granted medRxiv a license to display the preprint in It is made available under a CC-BY-ND 4.0 International license .

62

63

64

65

66

67

68

69

70

71

72

\section{Introduction}

Covid-19 originates from infection of the upper respiratory tract with SARS-CoV-2, which can progress into severe acute lung injury (ALI). Based on the tissue-typic expression of the viral host-entry receptor ACE2 and certain proteases (e.g. TMPRSS2) facilitating cellular uptake, also other organs like the kidney could be directly infected [1]. In addition, severe disturbance of immune and coagulation systems during covid-19 lead to a multifaceted disease with variable multi-organ damages [2]. A consistent finding in severe covid-19 is initial immune hyperactivation (called "cytokine storm") leading to subsequent immune exhaustion, a phenomenon also known in other severe infections [3-6]. Consequently, secondary infections which develop on top of SARS-CoV-2 infection contribute significantly to covid-19 mortality similar to severe influenza [7]. Curiously, the pathophysiology leading to the development of secondary lung infections is generally poorly understood. We performed an autopsy study of 20 consecutive covid-19 patients, who died during the first pandemic wave. Full autopsies were performed and various specimen types were collected for tissue-based investigations, molecular measures including deep sequencing and cultivation of virus and other microbes. Integrating all the information gained from this "holistic" autopsy approach allowed us to gain a deeper understanding of host and microbial factors contributing to secondary infections as a major sequel of lethal covid-19.

\section{Autopsy cohort, SARS-CoV-2 body distribution and genotyping}

Twenty consecutive covid-19 patients were examined post-mortem (Figure S1). Thirteen cases were males and 7 were females, their age ranged from 53 to 93 years (median: 79 years). All had multiple comorbidities typically prevalent in severe covid-19. In addition, 14 age-matched non-covid-19 controls who died within the same time period were included for 
medRxiv preprint doi: https://doi.org/10.1101/2022.02.18.22270995; this version posted February 19, 2022. The copyright holder for this preprint (which was not certified by peer review) is the author/funder, who has granted medRxiv a license to display the preprint in It is made available under a CC-BY-ND 4.0 International license .

comparisons (Tables S1 and S2). Patients were tested for SARS-CoV-2 tissue distributions by quantitative RT-PCR (target: nucleocapsid-gene) and most positive samples with the highest viral loads originated from the respiratory tract, followed by myocardium, liver, kidney and pleural effusions. Other tissues and body liquids were positive only in single cases or tested overall negative (Figure 1A). Notably, deep RNAseq generated from lung tissues revealed SARS-CoV-2 transcripts in each covid-19 case, including the four qRT-PCR negative ones, showing increased sensitivity of deep transcriptomic analysis $(127 \pm 29$ million reads were generated per sample on average; Figure 1B). The viral genome was entirely captured by deep RNAseq from lung tissues yielding more plus-strand reads (mean: 37.89 reads per million; range: $0.02-131,165.41)$ than minus-strand reads (mean: 1.81 reads per million; range: 0 484.81; Figure 1C). In addition, 11 SARS-CoV-2 strains could be cultivated from post-mortem lung tissues using Vero cells (Table S3). Successful virus cultivation significantly correlated with abundance of SARS-CoV-2 reads (Figure 1D and S2).

SARS-CoV-2 genotyping facilitated by PCR and sequencing directly from autopsy specimens yielded 14 complete viral genomes (Table S4). Nine different sequence variants were detected showing up to 12 nucleotide changes compared to the reference (SARS-CoV-2 Wuhan-Hu-1; total genome size 29,903 bp; Table S5). Strains corresponded to the pangolin lineages B.1.22, B1.5, B and B.1.160.1, respectively (clades 19A and 20A), representing the dominant genotypes of the first pandemic wave (Figure 1E). Twelve strains harbored a D614G mutation in the spike (S) protein, which leads to increased viral transmissibility and, therefore, this genotype superseded the wild-type strain already early in the pandemic [8]. We identified also 2 viral clusters in our cohort, cluster 1 (case 3, 4, 6, 8, and 9) and cluster 2 (case 1, 2, and 5), respectively (Figure 1F). 
medRxiv preprint doi: https://doi.org/10.1101/2022.02.18.22270995; this version posted February 19, 2022. The copyright holder for this preprint (which was not certified by peer review) is the author/funder, who has granted medRxiv a license to display the preprint in

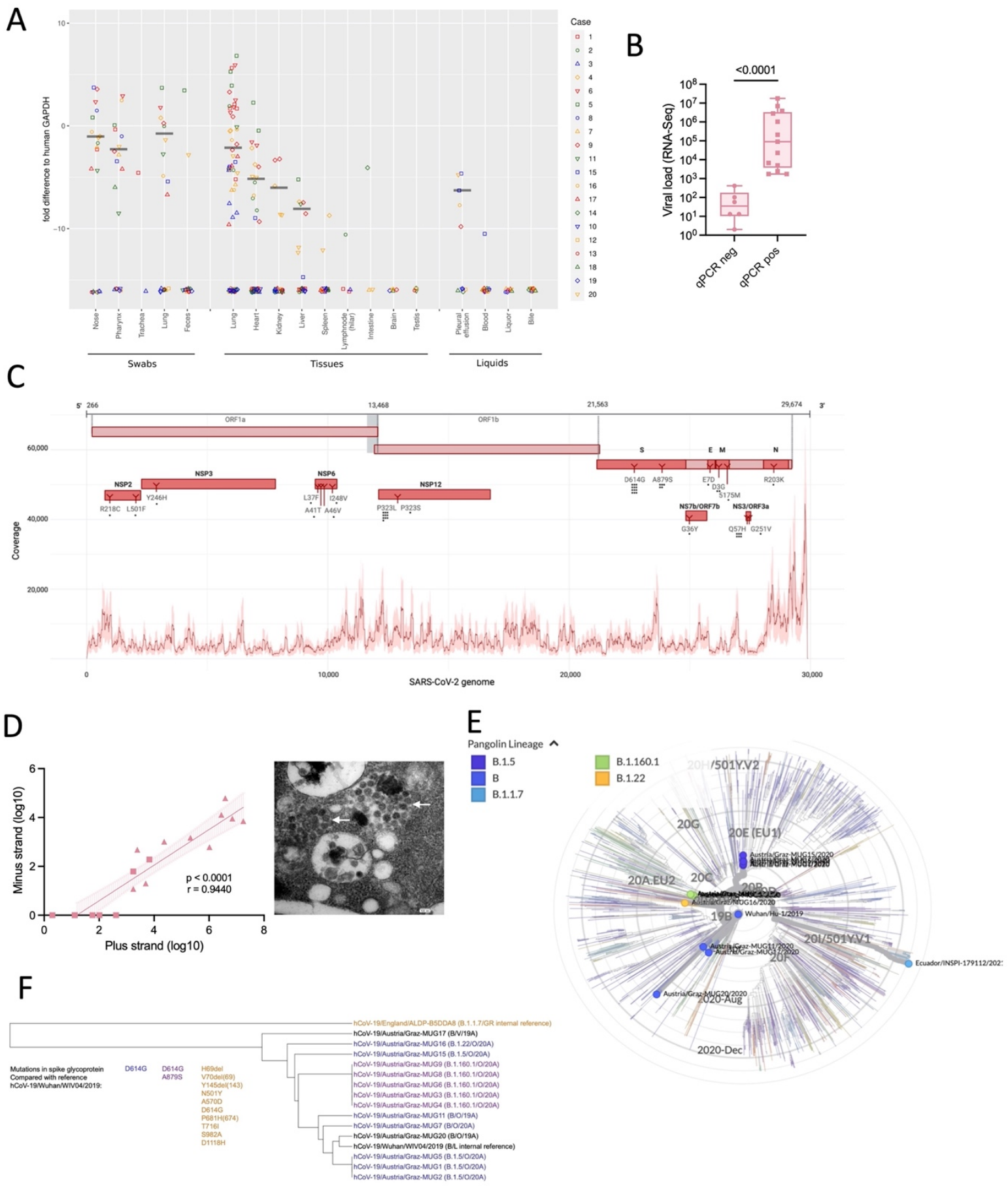

Figure 1. SARS-CoV-2 tissue distributions, genotyping and virus cultivation. (A) SARS-CoV-2 loads (compared to human glyceraldehyde 3-phosphate dehydrogenase, GAPDH) and tissue distributions derived from post mortem sampling (median highlighted). Case numbers are given on the right. (B) Significant association of qRT-PCR positivity (n-gene) with viral loads determined by RNAseq of lung tissues (Mann-Whitney test). (C) Distribution of viral reads generated from lung tissues along the SARS-CoV-2 genome. Cumulative coverage of plus and minus strand transcripts is shown (median in bold). Identified nucleotide and amino-acid 118 changes in comparison to the Wuhan reference strain are indicated. (D) Correlation of SARSCoV-2 plus and minus strand reads with cultivation (Spearman correlation). Triangles specify cultivation-positive samples. EM picture showing viral particles in Vero CCL-81 cells (arrows). (E) Cladogram showing detected virus genotypes within a global context. The Wuhan 
medRxiv preprint doi: https://doi.org/10.1101/2022.02.18.22270995; this version posted February 19, 2022. The copyright holder for this preprint (which was not certified by peer review) is the author/funder, who has granted medRxiv a license to display the preprint in

It is made available under a CC-BY-ND 4.0 International license .

122 reference strain (center) and the UK variant B.1.1.7 (Ecuador/INSPI-179112/2021) are

123 included for comparisons. The pangolin lineage designation is used to specify viral genotypes.

124 (F) Dendrogram showing detected viral genotypes. Corresponding mutations in the S protein

125 are indicated and virus strains are color coded accordingly.

126

127 Notably, cases 6,8 and 9 from cluster 1 originated from the same residential care home and

128 all cases from cluster 2 stayed in the same hospital ward prior to covid-19. Thus, it is very likely

129 that these individuals were infected from the same sources and/or transmission occurred.

Major organ pathologies and death causes

Lungs showed the dominant pathologies in relation to covid-19, only one case (\#1)

presented with acute myocardial infarction as the ascribed death cause. Diffuse alveolar

damage (DAD), the histopathological representation of $A L I$, in a patchy distribution and often

prevalent in multiple lung segments was the major finding in 11 cases. Early exudative stages

and later organizing stages of DAD were found within the same patient together, often

adjacent to nearly normal or less affected parenchyma indicating ongoing tissue damage

(Figures 2A and S3-S5). Also, a significant positive correlation of SARS-CoV-2 loads from

nasopharyngeal tissues compared to lungs was found (Figure 2B), which suggests active seeding of infectious particles from the upper respiratory tract likely via micro-aspiration into

141 the lungs [1]. Microscopic features of lungs were extensively assessed (see methods for details of scoring histopathological changes) to specify and grade the severity of lesions and also to capture the heterogeneity of different lung pathologies. Features greatly varied between cases and no pattern clearly correlated with disease duration (defined as the interval between the first SARS-CoV-2 positive PCR and death) or viral loads (Figure 2C). Importantly, the

146 clearest discriminating feature of cases was the presence of neutrophilic granulocytes,

147 indicative of secondary infections (i.e. "pneumonia"), in comparison to DAD. 
medRxiv preprint doi: https://doi.org/10.1101/2022.02.18.22270995; this version posted February 19, 2022. The copyright holder for this preprint (which was not certified by peer review) is the author/funder, who has granted medRxiv a license to display the preprint in perpetuity.

A

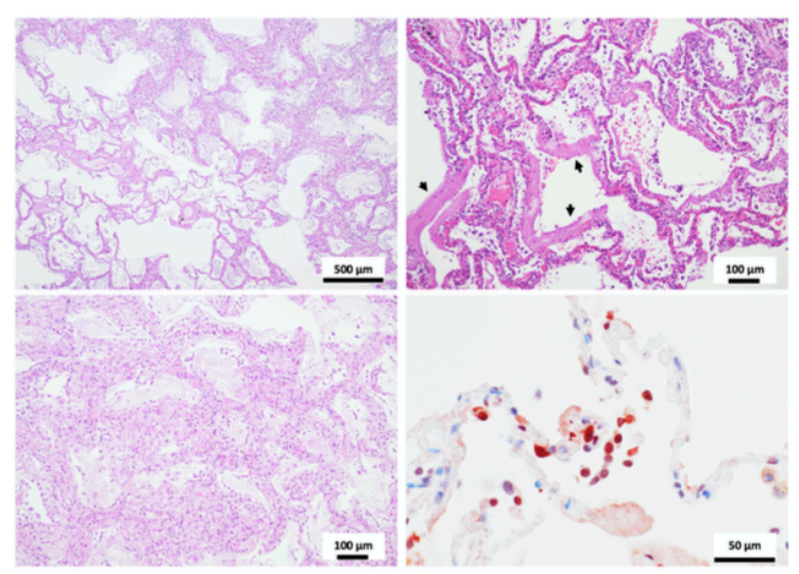

C

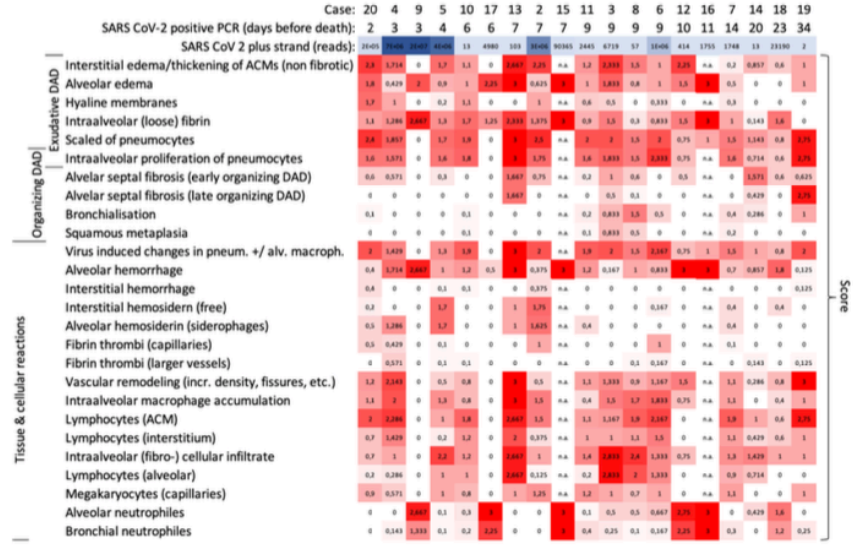

B
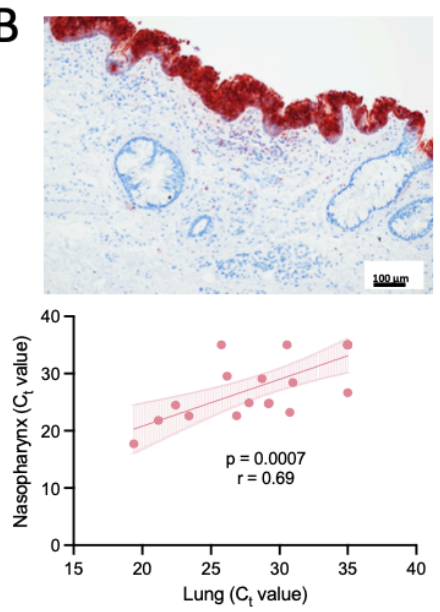

F

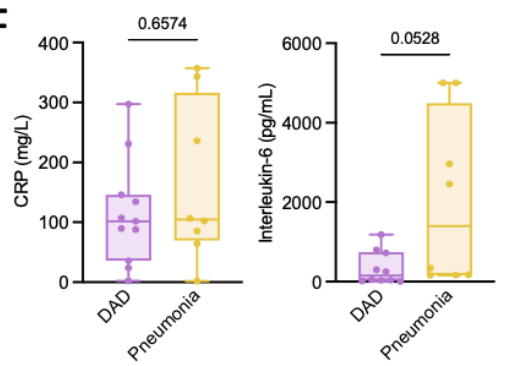

D

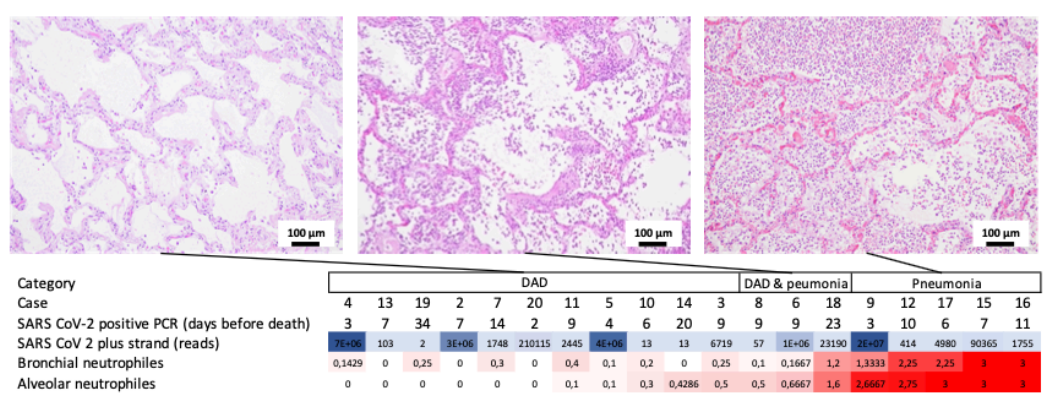

$\mathrm{E}$
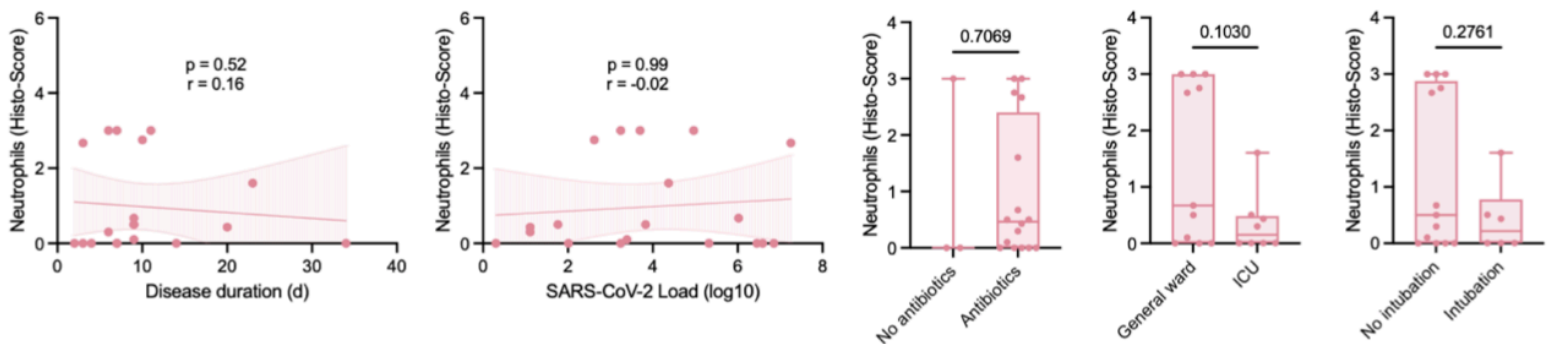

Figure 2. Lung pathology of lethal covid-19 stratifies into diffuse alveolar damage and pneumonia. (A) Histological representation of diffuse alveolar damage (DAD) in lungs. A patchy representation of DAD is shown (left). Hyaline membranes (arrows) as a hallmark lesion of early DAD (top right). Immunohistochemical detection (nucleoprotein antibody) of SARS-CoV-2 infected pneumocytes (bottom right). (B) (Top) Immunohistochemical detection of SARS-CoV-2 infected respiratory epithelium of the nasopharynx. (Bottom) Correlation between SARS-CoV-2 loads in the nasopharyngeal mucosa and lung tissue determined by qRTPCR (Spearman correlation). (C) Scoring of prevalent histopathology patterns in lungs. Cases 
medRxiv preprint doi: https://doi.org/10.1101/2022.02.18.22270995; this version posted February 19, 2022. The copyright holder for this preprint (which was not certified by peer review) is the author/funder, who has granted medRxiv a license to display the preprint in

It is made available under a CC-BY-ND 4.0 International license .

are ordered according to duration of disease. (D) Main discrimination of lung pathology according to DAD and pneumonia patterns. Cases are ordered according to alveolar neutrophil counts. (E) Correlation analyses of neutrophil abundance and clinical parameters (Spearman correlation; Mann-Whitney test). (F) Serum C-reactive protein (CRP) and interleukin-6 (IL-6) levels (Mann-Whitney test) in DAD versus pneumonia cases.

Three cases showed DAD superimposed with acute inflammation and 5 cases showed mainly pneumonia as the dominant pathology, wherein DAD was only focally visible overlaid with dense inflammation. Altogether, 16 cases showed neutrophilic granulocytes present in bronchi, bronchioli or alveoli suggestive of secondary infections. Thus, lung histopathology in lethal covid-19 could be stratified into DAD, DAD superimposed with pneumonia and dominating pneumonia (Figures 2D and S3). Noteworthy, neither disease duration nor viral loads correlated with presence of neutrophils, nor did any other clinical parameter (Figures $2 \mathrm{E}$ and $\mathrm{S6}$ ), however, pneumonia cases showed increased IL-6 levels compared to pure DAD cases, whereas CRP levels did not differ between categories (Figure 2F). Other organs showed features of preexisting comorbidities including arteriosclerosis, hypertension and diabetes, especially in the kidneys, wherein SARS-CoV-2 could be detected in tubular epithelia by positive immunohistochemistry (Figure S7). Heart and liver specimens revealed no clear evidence of direct SARS-CoV-2 carriage nor features of myocarditis or hepatitis (Figures S8 and S9). A detailed summary of organ histopathologies is given in the supplementary appendix (Table S6).

\section{Lung microbiome alterations and secondary-infections in lethal covid-19}

The lung microbiome is altered in DAD and thought to be a relevant factor for the development of secondary infections $[9,10]$. RNAseq data from lung tissues was screened for microbial sequences and bacterial (16S rRNA gene) and fungal (internal transcribed spacer, ITS) marker genes were amplified to additionally specify microbial changes. On average 
medRxiv preprint doi: https://doi.org/10.1101/2022.02.18.22270995; this version posted February 19, 2022. The copyright holder for this preprint (which was not certified by peer review) is the author/funder, who has granted medRxiv a license to display the preprint in It is made available under a CC-BY-ND 4.0 International license.

185

186

187

188

189

190

191

192

193

194

195

196

197

198

199

200

201

202

203

204

205

$6573.33 \pm 2552.32(\mathrm{MW} \pm \mathrm{SD}$ ) reads per million (rpm) per sample were not human in RNAseq and likely of microbial origin, of those $2.02 \pm 4.00 \%$ and $0.03 \pm 0.05 \%$ could be clearly annotated to specific microbes with different microbial annotation pipelines (Figure 3A). Excluding SARS-

CoV-2 reads, which were the dominant microbial component in several cases (range: $0.01-$ $131218.36 \mathrm{rpm})$, bacterial sequences were dominant, significantly increased in covid-19 cases with pneumonia compared to DAD and controls. Fungal and viral sequences other than SARSCoV-2 were also significantly enriched in covid-19 cases with pneumonia (Figure 3B). Number of bacterial reads significantly correlated with neutrophil scores suggesting that their presence is a sign of secondary infections, however, the post-mortem interval did not, precluding a strong influence of post-mortal bacterial overgrowth in our investigation (Figure 3C). Bacteria are assumed to be the dominant microbiome component in lungs [11]. Analysis based on the bacterial 16S rRNA gene marker showed that richness was significantly decreased in the DAD and pneumonia cases of covid-19 compared to controls indicating an overall reduced biodiversity (Figure 3D). In contrast, evenness was significantly decreased in the pneumonia group of covid-19 only, suggesting a dominance of certain taxa, possibly representing the agents of secondary infections (pairwise Kruskal-Wallis; ${ }^{*} p<0.05$, $\left.{ }^{* *} p<0.005\right)$. Principal component analysis $(P C A)$ clearly separated controls from covid-19 cases with DAD and cases with pneumonia indicating significantly different bacterial community compositions (Figure 3D). Lung tissues were also cultured for bacteria and fungi and both, covid-19 cases and controls, yielded cultivable microorganisms but in different quantities and taxonomic constellations (Table S7). 
medRxiv preprint doi: https://doi.org/10.1101/2022.02.18.22270995; this version posted February 19, 2022. The copyright holder for this preprint (which was not certified by peer review) is the author/funder, who has granted medRxiv a license to display the preprint in It is made available under a CC-BY-ND 4.0 International license

A

B

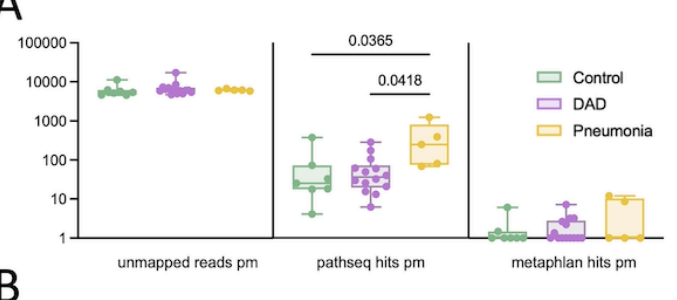

$\mathrm{C}$
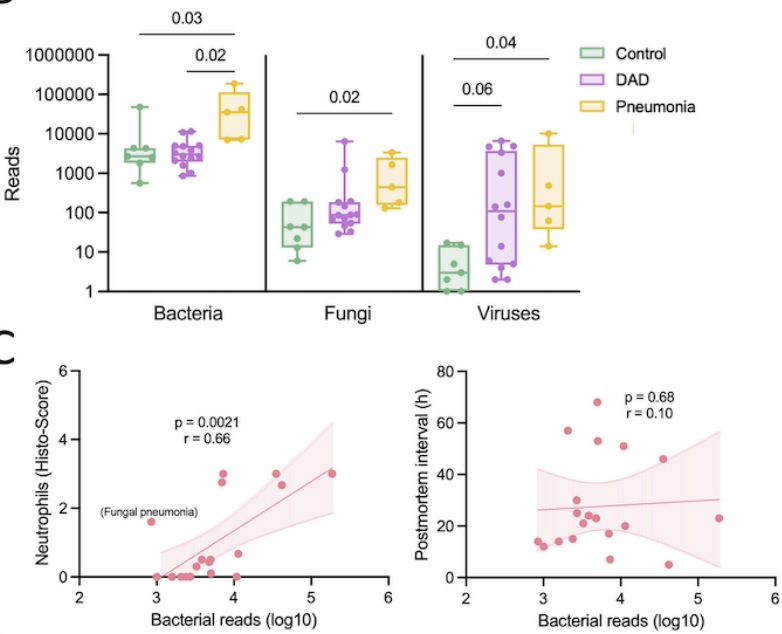

D

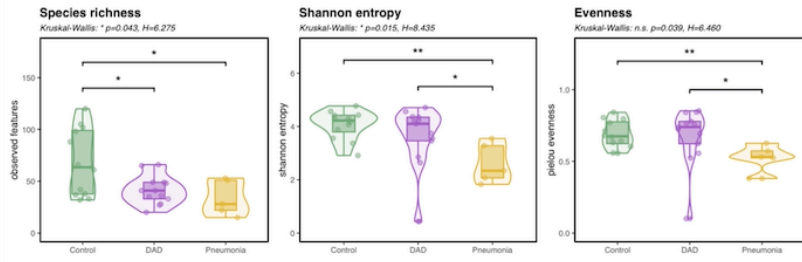

$\mathrm{E}$
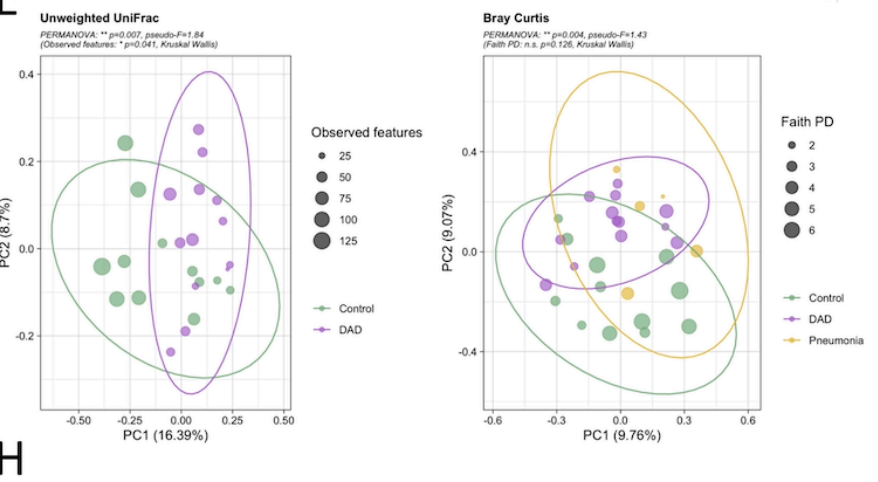

$\mathrm{F}$

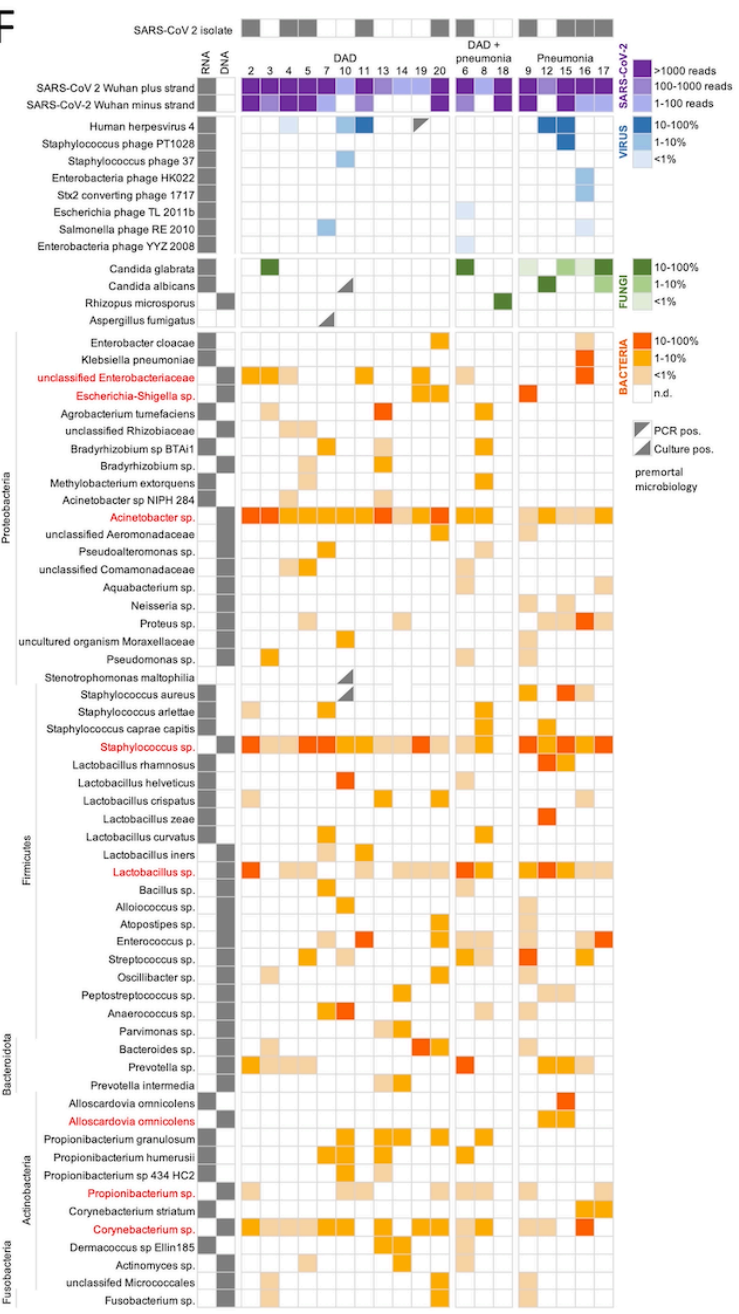

G

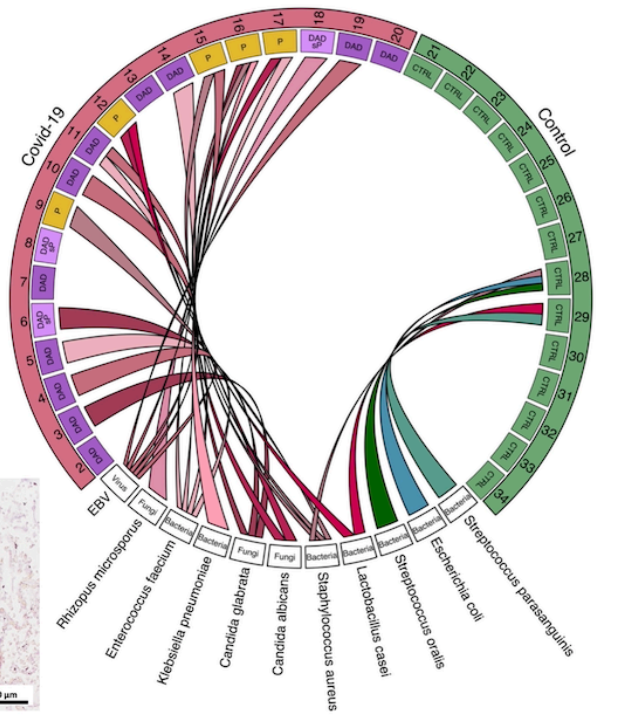

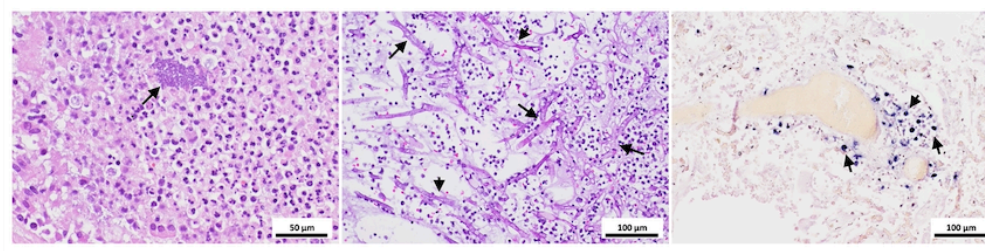

207 Figure 3. Microbiome alterations and agents of secondary infections in covid-19 lungs. (A)

208 Annotation of non-human transcripts to microbial sequences with PathSeq and MetaPhIAn, respectively. (B) Significantly increased bacterial, fungal and viral reads in the pneumonia category of covid-19 (PathSeq annotation, Kruskal-Wallis test). (C) Bacterial reads significantly correlate with neutrophil counts but not with the post-mortem interval (Spearman correlation). (D) Richness and evenness in the bacterial component of the lung microbiome (based on the 16S rRNA gene marker). (E) Beta-diversity analysis (PCA based on unweighted 
medRxiv preprint doi: https://doi.org/10.1101/2022.02.18.22270995; this version posted February 19, 2022. The copyright holder for this preprint (which was not certified by peer review) is the author/funder, who has granted medRxiv a license to display the preprint in

It is made available under a CC-BY-ND 4.0 International license .

214 UniFrac and Bray Curtis distance) clearly separates DAD and pneumonia cases of covid-19

215 from controls (16S rRNA gene). (F) Summary of bacterial, fungal and viral microbes prevalent

216 in covid-19 lungs. Shown are microbes detected by cultivation, RNA and/or DNA sequencing.

217 (G) Dominant pathogens causing secondary infections in covid-19 lungs compared to controls

218 (summary of cultivation and deep sequencing). (H) Microscopic representation (H\&E) of

219 bacterial (left, case \#16) and fungal (middle, case \#18) pathogens in lung tissues. Epstein Barr

220 virus RNA positivity in lung tissue (EBV RNA in-situ hybridization, case \#11).

221

222 Finally, we integrated RNAseq, 16S, ITS and culture data to define dominant pathogens, most

223 likely representing the agents of secondary infections and to account for the different samples

224 used for microbial identifications in the light of the patchy disease representations likely

225 impacting the microbial repertoires (Figure S10, Table S8). Dominant pathogens were defined

226 if they were dominant in the RNA and/or DNA data (representing $>10 \%$ of microbial reads

227 excluding SARS-CoV-2) and if they also yielded a reasonable culture growth $\left(\geq 10^{4} \mathrm{cfu} / \mathrm{ml}\right)$.

228 Dominant taxa were typical agents of pulmonary secondary infections like Staphylococcus

229 aureus, Enterococcus faecium or Klebsiella pneumoniae, as well as fungi like Candida spp. or

230 the mold Rhizopus microsporus identified in one case (\#18). Often multiple pathogens were

231 found simultaneously indicating polymicrobial infections (e.g. in case \#16 wherein $K$.

232 pneumonia, S. aureus and C. glabrata were cultivated in reasonable amounts and were also

captured by RNAseq). In addition, 5 covid-19 cases yielded transcripts of Epstein Barr virus

234 (EBV), which were also detectable by RNA in-situ hybridization of lung tissues but not in

controls (Figure $3 \mathrm{H}$ ). EBV often emerges due to endogenous reactivation in the context of

impaired immunity [12]. Control cases yielded microbial sequences and cultivable microbes in

237 lower quantity and they often belonged to known contaminants like Lactobacillus sp. or

reduced taxonomic richness but harbors a diverse spectrum of bacterial and fungal pathogens 
medRxiv preprint doi: https://doi.org/10.1101/2022.02.18.22270995; this version posted February 19, 2022. The copyright holder for this preprint (which was not certified by peer review) is the author/funder, who has granted medRxiv a license to display the preprint in It is made available under a CC-BY-ND 4.0 International license .

MERS $[13,14]$. Notably, secondary infections were rarely detected ante-mortem in our cohort

243 (Table S8). The presence of poly-microbial infections and the relatively high proportion of EBV

244 positivity suggests an overall impaired immunity in covid-19 lungs.

The lung metatranscriptome mirrors the major death categories DAD and pneumonia.

indicated impaired central cellular functions within mRNA metabolism, post-translational protein modification, the respiratory chain, VEGFA signaling and extracellular matrix functions, neutrophil degranulation, cytokine signaling as well as complement activation

(Figure 4B). Overall, these data confirm profound and complex transcriptional alterations in covid-19 lung tissue [15-17]. Unsupervised principal components analysis (PCA) of differentially expressed genes clearly separated covid-19 samples on principal component 1 (PC1) from controls but also clearly separated pneumonia samples from pure DAD cases (Figure 4C). Comparison of differentially expressed genes between these major death categories indicated that the major discriminator from controls was DAD showing 3862 unique differentially expressed genes (adj. $\mathrm{P}<0.05$ and abs LFC $>=0.58$ ) followed by pneumonia with 1673 unique differentially expressed genes (Figure 4D). DAD and pneumonia differed by only 226 differentially expressed genes. Notably, amongst the top 50 differential expressed genes enriched in pneumonia cases several macrophage markers were evident, including the receptor ADGRE1 (murine homolog F4/80) as top-hit, the interleukin-1 receptor-associated 
medRxiv preprint doi: https://doi.org/10.1101/2022.02.18.22270995; this version posted February 19, 2022. The copyright holder for this preprint (which was not certified by peer review) is the author/funder, who has granted medRxiv a license to display the preprint in It is made available under a CC-BY-ND 4.0 International license.

A

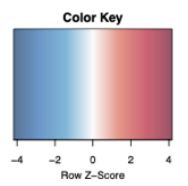

-Covid cases

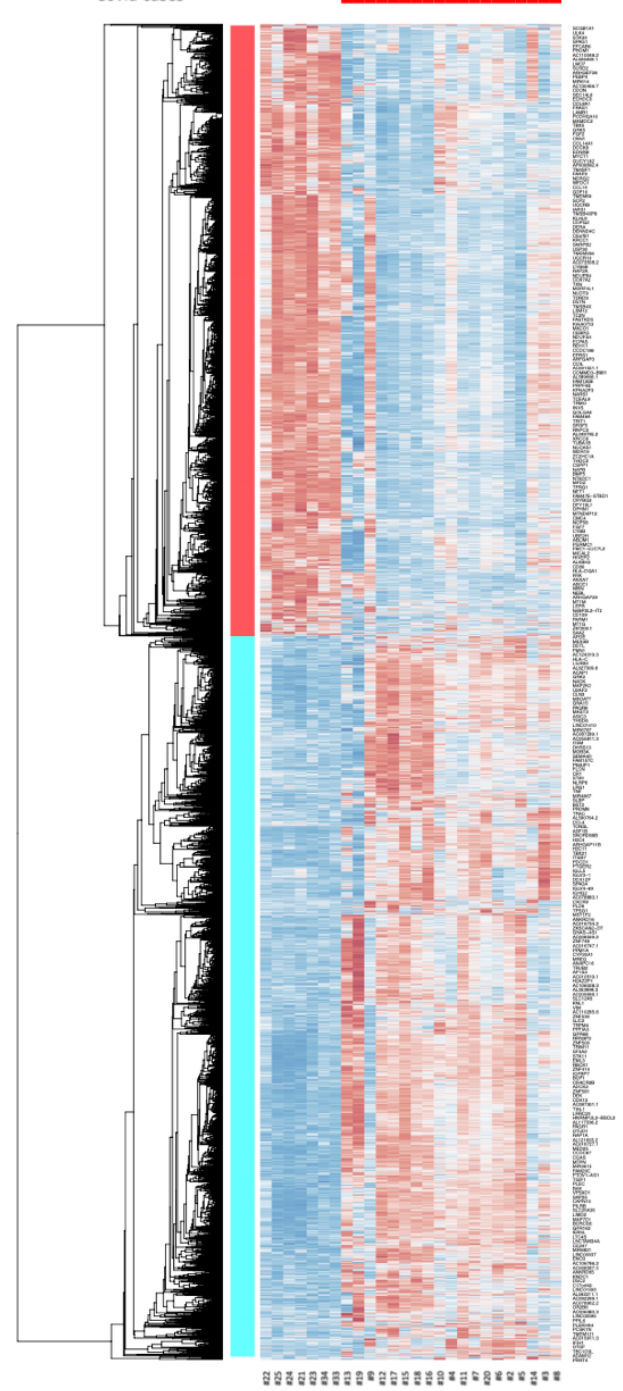

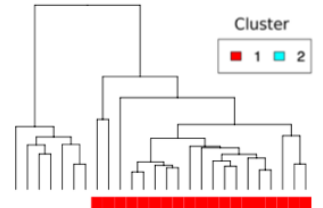

C

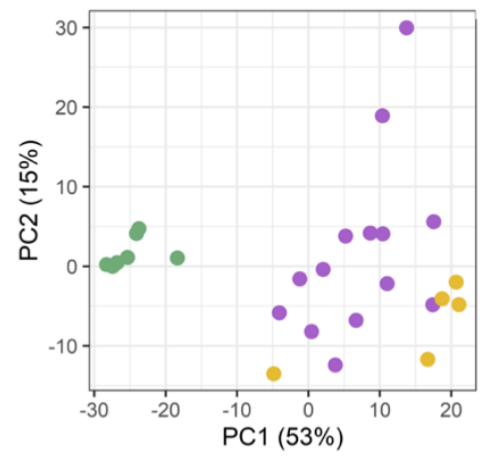

B

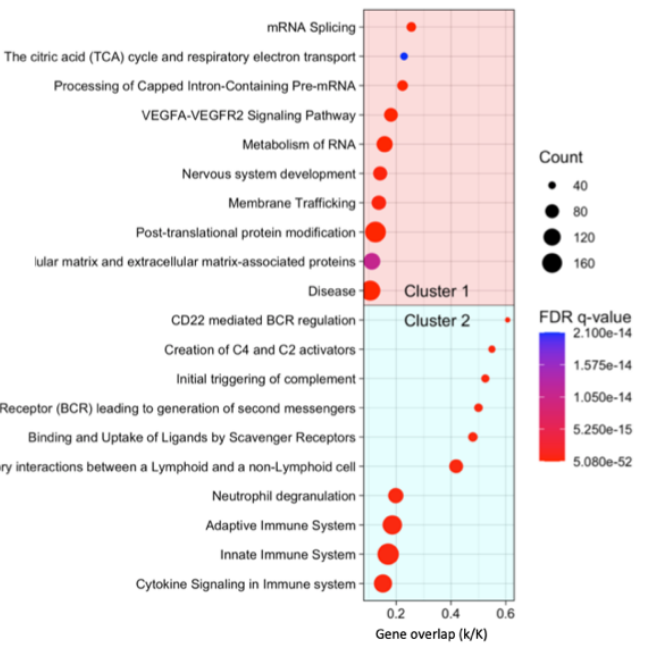

Group

- Control

- DAD

- Pneumonia
D

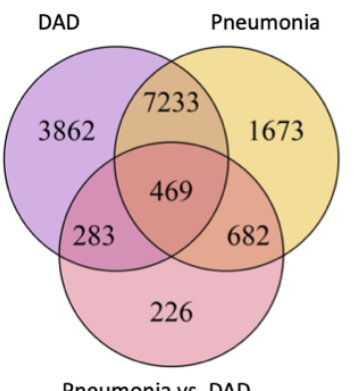

Pneumonia vs. DAD

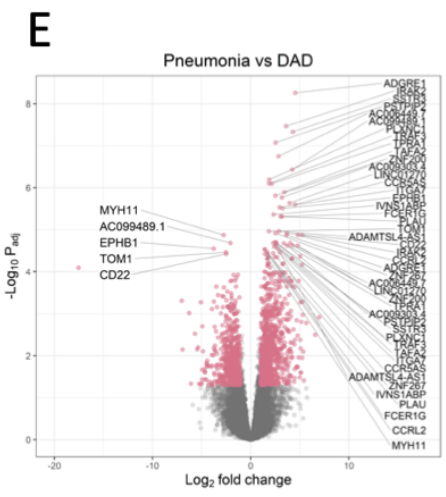

Figure 4. The lung metatranscriptome mirrors the major death categories DAD and pneumonia. (A) Hierarchical clustering shows depleted (cluster 1) and enriched (cluster 2) genes $(n=4,547$; adj. $P<0.05)$ in lung tissue of covid-19 cases compared to controls. (B) Gen set enrichment analysis (canonical pathways) of major depleted (top) and enriched (bottom) pathways in covid-19 lungs. (C) PCA based on differentially expressed genes clearly discriminates DAD cases and cases with secondary pneumonia of covid-19 from controls. (D) Venn diagram specifying differentially expressed genes in DAD as the major discriminator followed by pneumonia (adj. $P<0.05, L F C \geq 0.58$ ). (E) Volcano plot showing the top 25 significantly deregulated genes in secondary pneumonia versus DAD. Several macrophage genes are increased. 
medRxiv preprint doi: https://doi.org/10.1101/2022.02.18.22270995; this version posted February 19, 2022. The copyright holder for this preprint (which was not certified by peer review) is the author/funder, who has granted medRxiv a license to display the preprint in It is made available under a CC-BY-ND 4.0 International license .

279 Thus, macrophages seem to be implicated in covid-19 secondary infections. In summary, deep

280 transcriptomic analyses specified multiple dysregulated processes in covid-19, including

281 vascular and coagulation systems, connective tissue remodeling as well as activated immunity

282 and complement [18]. Similar to histopathology, the major discriminator from controls based

283 on gene expression was DAD followed by pneumonia likely mirroring the development of

284 secondary infections on top of ALI caused by the virus.

285

Cellular deconvolution subgroups covid-19 lung pathology.

Cellular compositions were inferred from deep RNAseq data by using xCell [19].

Hierarchical clustering based on cellular compositions clearly separated samples into four

distinct groups. Group 1 ("control") consisted only of control cases and was related to group

2 ("DAD1") consisting of covid-19 cases with pure DAD (in addition to one control case \#22).

291 Group 3 ("DAD2") contained also DAD cases, including one sample with the histological

292 category DAD and secondary pneumonia. This group was related to group 4 ("pneumonia")

composed of all pneumonia cases, in addition to 3 DAD cases and the two remaining DAD

cases with secondary pneumonia (Figure 5A). Noteworthy, neither disease duration nor SARS-

CoV-2 loads clearly correlated with a specific grouping. Cell types discriminating these groups

showed a specific assembly (Figure 5B). Cluster 1 consisted mainly of vascular and stromal cell types like endothelial cells, pericytes and fibroblasts, enriched in "DAD1" and "DAD2". Top enriched genes in this cluster were certain collagen genes, the vascular transcription factor sox 18 , the basement membrane protein ladinin-1 or the endothelial protein stabilin-1 (Figure certain immune and blood cell types and they were overall reduced in covid-19. 
medRxiv preprint doi: https://doi.org/10.1101/2022.02.18.22270995; this version posted February 19, 2022. The copyright holder for this preprint (which was not certified by peer review) is the author/funder, who has granted medRxiv a license to display the preprint in perpetuity.

It is made available under a CC-BY-ND 4.0 International license .
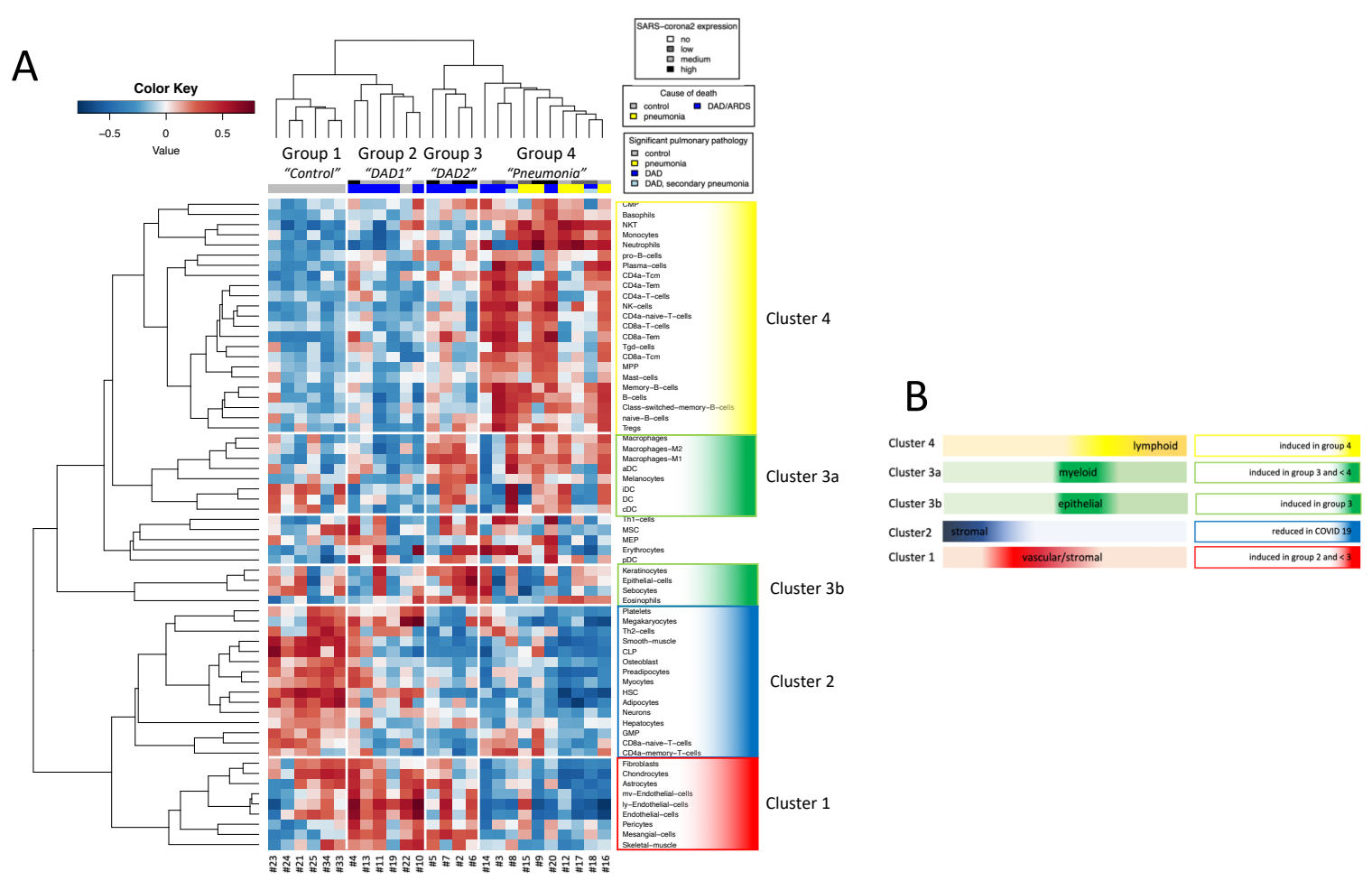

C
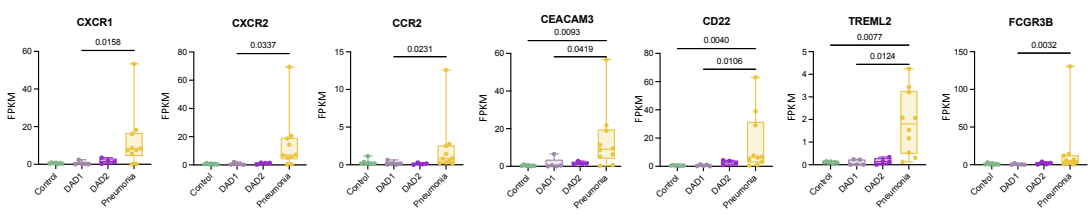

Cluster $3 a$
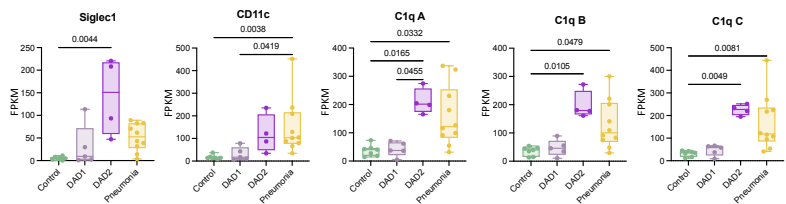

Cluster 3b
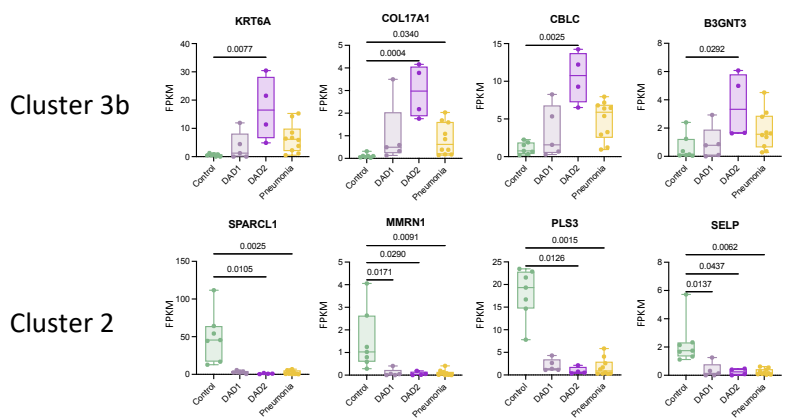

Cluster 1
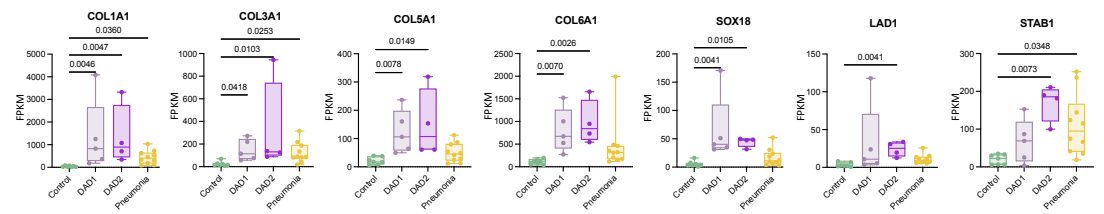

Figure 5. Cellular deconvolution stratifies lung pathology sub-groups. (A) Hierarchical grouping of samples. (B) Scheme indicating cell clusters which discriminate different groups. (C) Top induced genes in the respective cell clusters determining the specific grouping (Kruskal-Wallis test). 
medRxiv preprint doi: https://doi.org/10.1101/2022.02.18.22270995; this version posted February 19, 2022. The copyright holder for this preprint (which was not certified by peer review) is the author/funder, who has granted medRxiv a license to display the preprint in It is made available under a CC-BY-ND 4.0 International license .

Top down-regulated genes included the extracellular matrix proteins sparc-like 1, multimerin1 and plastin-3 or the cell adhesion molecule p-selectin important for the recruitment of leukocytes typically prevalent on activated endothelial cells and platelets (Figure 5C). Together these alterations highlight the vascular and connective tissue changes emerging during DAD development (Figure 2B) [20, 21]. Cell types of cluster 3, which were dominantly induced in "DAD2" and to a lesser extent in "pneumonia" showed enrichment of myeloid (cluster 3a) and epithelial cell types (cluster 3b). Top induced genes in cluster 3a were the myeloid cell specific genes siglec-1, CD11c and complement factor C1q. Top induced genes in cluster $3 \mathrm{~b}$ consisted of keratin $6 \mathrm{~A}$, collagen $X V I I$, the tyrosine kinase signaling protein $c b l-c$ and beta-1,3-N-acetylglucosaminyltransferase 3 (b3gnt3), typically expressed in epithelia and also involved in lymphocyte trafficking and homing. Cell types in cluster 4, strongly increased in "pneumonia" consisted of different leukocyte classes including B-, T-cells and (neutrophilic) granulocytes. Top induced genes consisted of the interleukin 8 receptor genes $c x c r 1$ and $c x c r 2$, the chemokine receptor type 2 (CCR2), CEACAM3, CD22 (B cell marker), and the cell surface receptors TREML2 and FCGR3B.

In summary, cellular deconvolution clearly sub-stratified the major categories DAD and pneumonia of covid-19 lung pathology. Noteworthy, DAD subclustered into two different groups, one showing mainly induction of vascular and stromal cell elements ("DAD1"), the other dominant induction of genes related to myeloid and epithelial cells ("DAD2"), and this subgroup showed more commonalities with the pneumonia group.

\section{Macrophages, complement c1q and immune impairment in covid-19 lungs}

Myeloid cells including macrophages play a central role in the pathogenesis of DAD [22-24], and bronchioloalveolar lavage fluids (BALF) of patients with severe covid-19 show 
medRxiv preprint doi: https://doi.org/10.1101/2022.02.18.22270995; this version posted February 19, 2022. The copyright holder for this preprint (which was not certified by peer review) is the author/funder, who has granted medRxiv a license to display the preprint in It is made available under a CC-BY-ND 4.0 International license.

high proportions of macrophages $[15,25]$. We confirmed significantly increased macrophages in covid-19 lungs by CD163 Immunohistochemistry, a M2-type macrophage marker (Figure $6 A)$, corroborating a recent proteomic study wherein CD163 was found amongst the most induced proteins in lungs and spleens derived from covid-19 autopsies [18]. Deconvolution indicated both M1- and M2-type macrophages significantly enriched predominantly in "DAD2" whereas monocytes were mainly induced in the "pneumonia" group (Figure 6B). Increased CD163 positive macrophages gathering around virus positive cells were recently shown also in a macaque model of SARS-CoV infection, indicating that infected pneumocytes may lead to macrophage recruitment in coronavirus infections [26].

Among the most discriminative genes between DAD subtypes we found complement factor C1q dominantly induced in "DAD2" (Figure 5C). Complement activation is implicated in DAD pathogenesis and linked to severe covid-19 [27-29]. Other complement factors showed no discriminative expression pattern between pathological subgroups in our cohort, except certain complement receptors and properdin mainly induced in pneumonia cases (Figure 6C). Western blots generated from protein extracts of lungs confirmed significantly increased C1q (Figure 6D). A major source of $\mathrm{C1q}$ are macrophages corroborated also by a recent single-cell transcriptomic analysis of covid-19 lungs (Figure S11) [30, 31] suggesting a strong connection between macrophages and complement C1q in covid-19 [32]. Immunohistochemical analysis of lung tissues with a C1q antibody showed staining of the vasculature, the interstitial and alveolar space but also of alveolar cells including macrophages and pneumocytes, indicating a multifaceted deposition of C1q in the context of covid-19 in our series (Figure 6E). 
medRxiv preprint doi: https://doi.org/10.1101/2022.02.18.22270995; this version posted February 19, 2022. The copyright holder for this preprint (which was not certified by peer review) is the author/funder, who has granted medRxiv a license to display the preprint in perpetuity.

It is made available under a CC-BY-ND 4.0 International license .

A
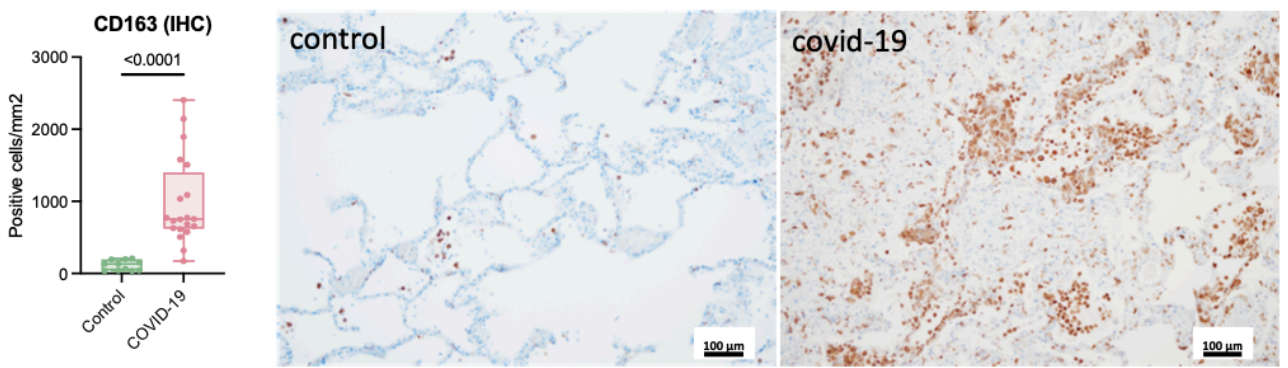

B
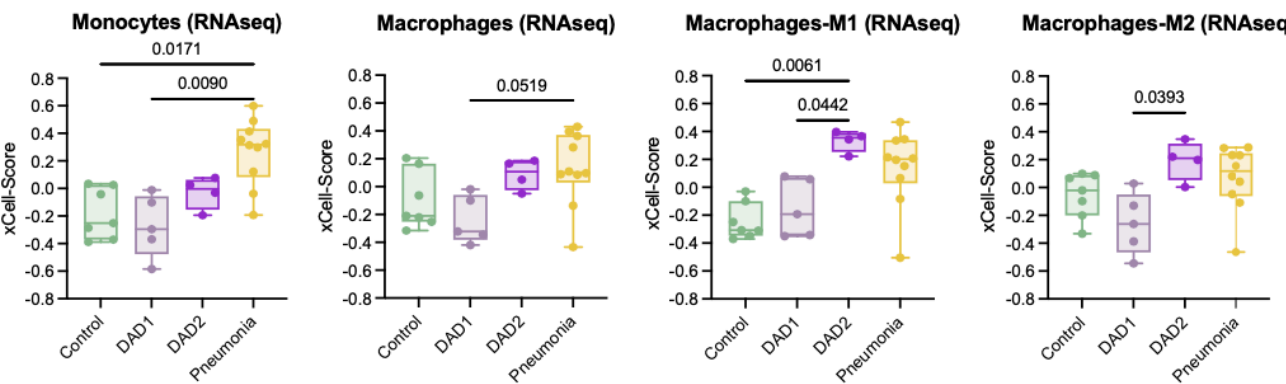

C

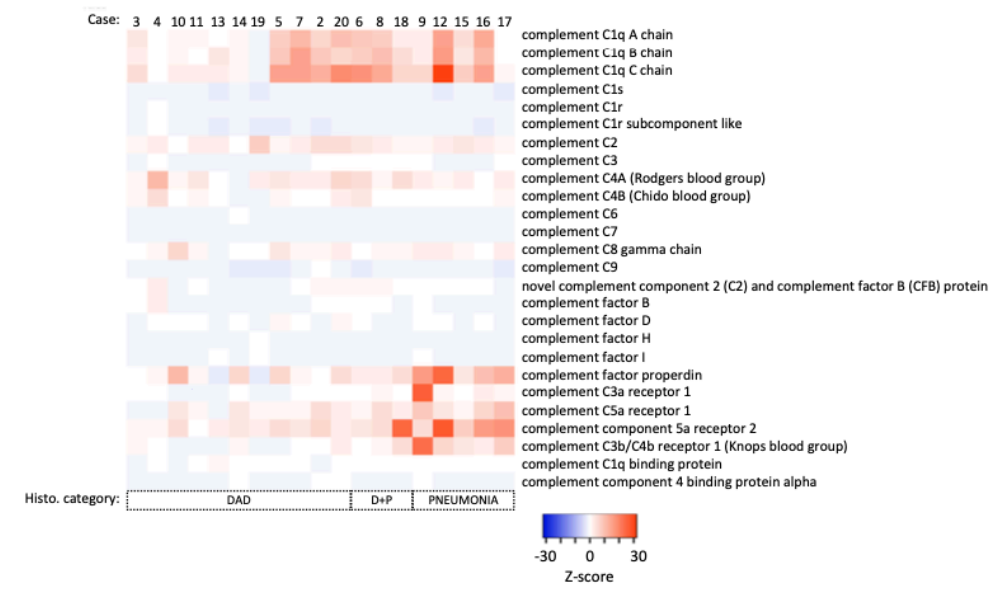

D

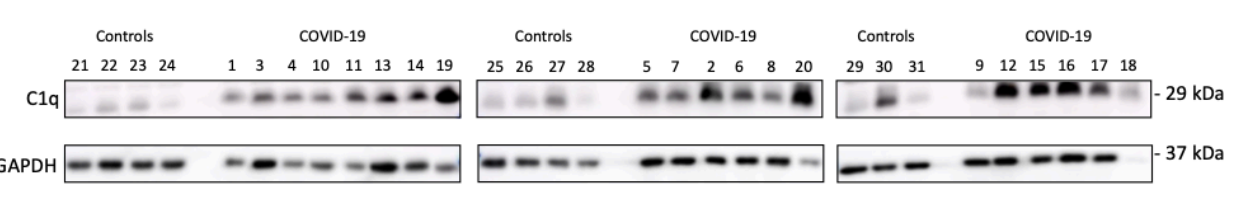

$E$
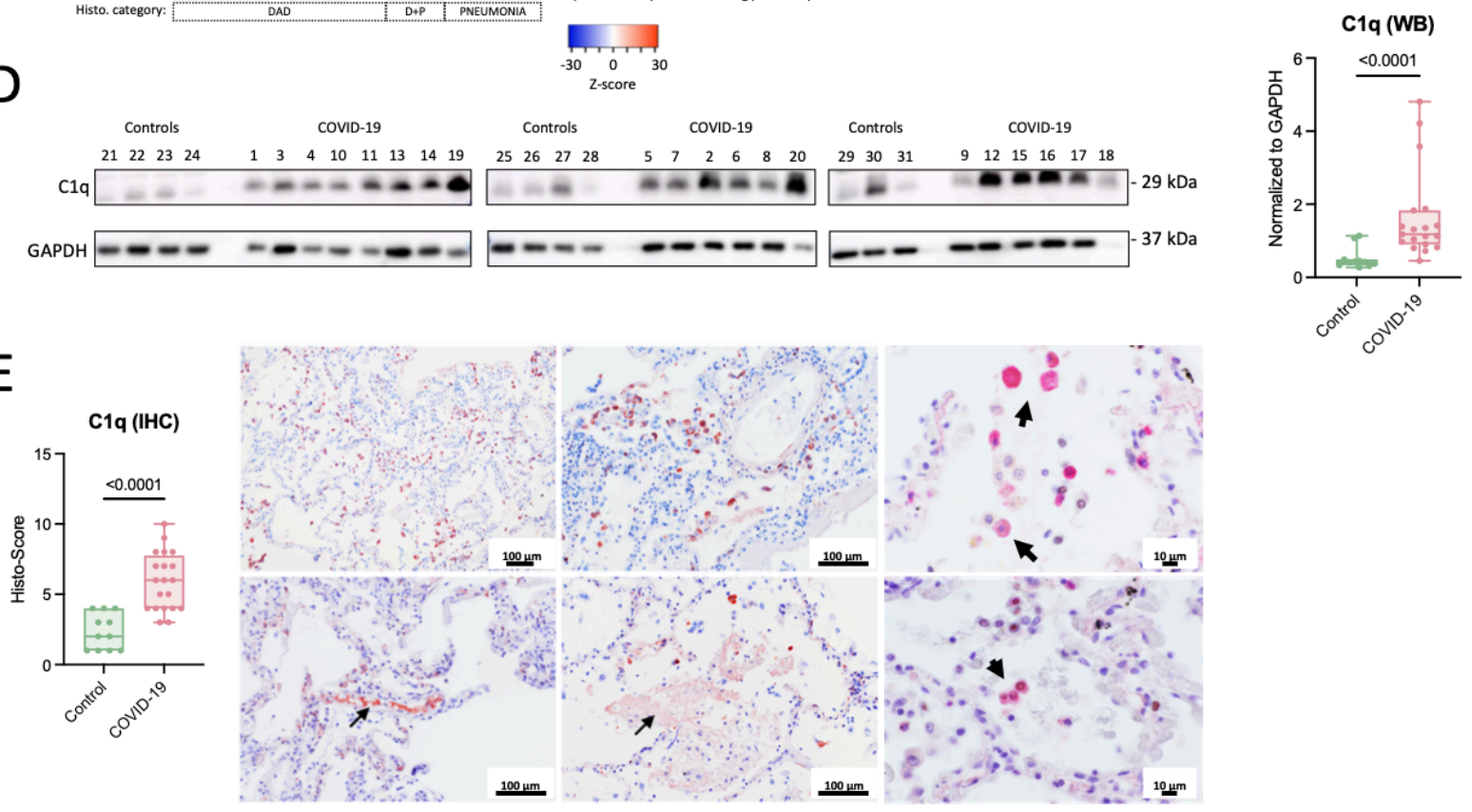

Figure 6. Macrophage and complement $\mathrm{C} 1 \mathrm{q}$ induction in covid-19 lungs. (A) Immunohistochemical counting of CD163 positive macrophages shows induction in covid-19 compared to controls (Mann-Whitney test). (B) Both M1 and M2 macrophages are specifically increased in "DAD2" compared to "DAD1" (grouping according to xCell analysis; Kruskal-Wallis test). (C) Heatmap of complement genes specifies $C 1 q$ induction in a subgroup of DAD cases 
medRxiv preprint doi: https://doi.org/10.1101/2022.02.18.22270995; this version posted February 19, 2022. The copyright holder for this preprint (which was not certified by peer review) is the author/funder, who has granted medRxiv a license to display the preprint in

It is made available under a CC-BY-ND 4.0 International license .

363

364

365

366

367

368

369

370

371

372

373

374

375

376

377

378

379

380

381

382

383

384

385

386

387

388

389

390

and in pneumonia. (D) C1q protein (29 kDa) is significantly increased in covid-19 lung tissue compared to controls (reference human GAPDH; Mann Whitney test). (E) Significant Induction of $\mathrm{C} 1 \mathrm{q}$ detected by immunohistochemistry (Mann Whitney test) and different staining patterns in covid-19 lungs; top left \& middle: C1q staining of alveolar cells; top right: double immunohistochemistry staining (red: C1q, nuclear black: TTF-1) shows C1q staining of alveolar macrophages; bottom left: intravascular C1q staining; bottom middle: free C1q specific staining of proteinaceous fluid in the alveolar space; bottom right: double immunohistochemistry staining (red: C1q, nuclear black: TTF-1) shows C1q staining of pneumocytes (TTF-1 positive) .

$\mathrm{C} 1 \mathrm{q}$ is the initiating component of the classical complement cascade but exhibits also immune regulatory functions. It induces the development of pro-resolving $\mathrm{M} 2$ type macrophages and is involved in the clearance of apoptotic and necrotic cells, which are highly increased in covid19 lungs [33-35]. In this process C1q binds to cellular break-down products and is subsequently recognized by phagocyte receptors like the leukocyte-associated immunoglobulin-like receptor 1 (LAIR-1; syn.: CD305) conferring uptake and triggering a tolerogenic state in the phagocyte [36, 37]. As shown by a recent single-cell transcriptomics analysis of covid-19 lungs, LAIR-1 is mainly present in macrophages (Figure S12) [17]. LAIR-1 together with LILRB4 (leukocyte immunoglobulin-like receptor subfamily B member 4; syn.: ILT3) belong to immunoglobulin-like receptors recognizing collagen domains such as present in C1q, thereby inhibiting immune activation $[38,39]$. RNAseq confirmed significant induction of LAIR-1 and LILRB4 dominantly in "DAD2" followed by "pneumonia" (Figure 7A). Expressions of all 3 C1q polypeptide chains $(A, B \& C)$ significantly correlated with LAIR-1 and LILRB4 expression but not with induced collagens (Figures 7B and S13). This might suggest a functional link between C1q and the immune inhibitory receptors LAIR-1 and LILRB4. 
medRxiv preprint doi: https://doi.org/10.1101/2022.02.18.22270995; this version posted February 19, 2022. The copyright holder for this preprint (which was not certified by peer review) is the author/funder, who has granted medRxiv a license to display the preprint in

A
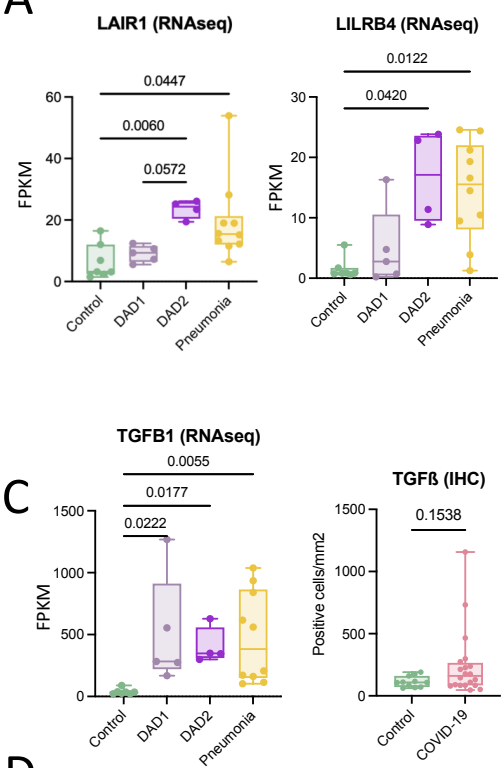

D

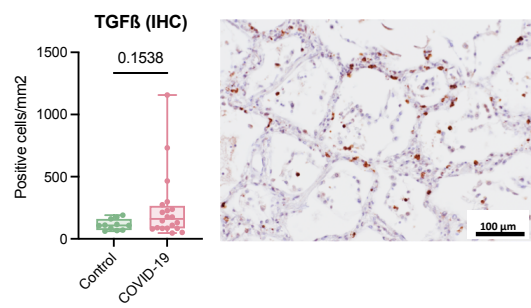

E
B

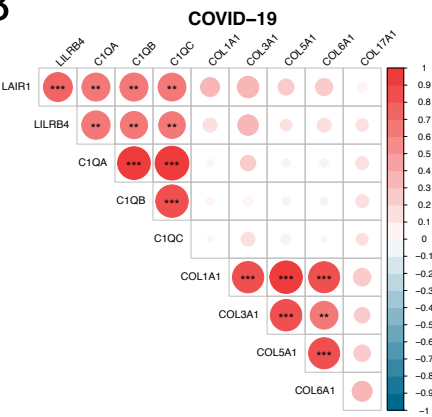

Control

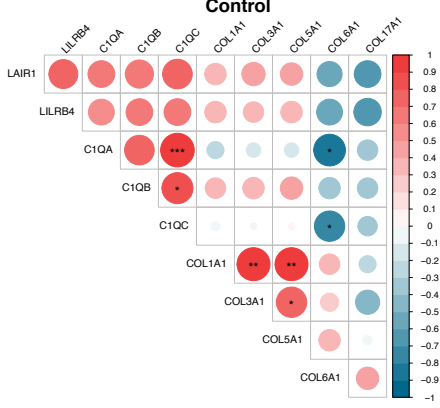

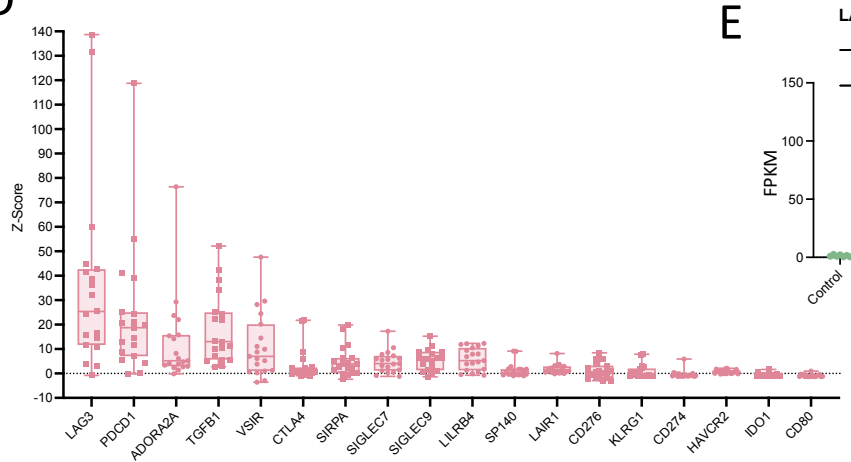

$\mathrm{F}$

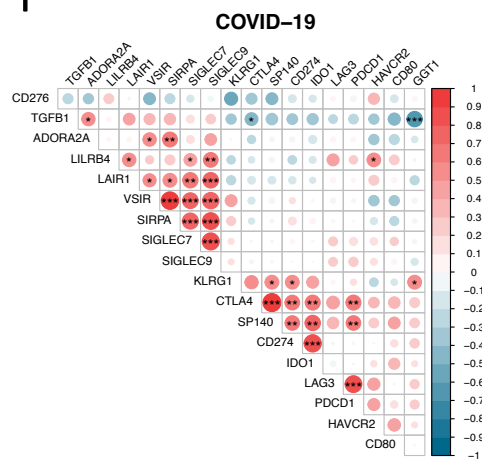

Control

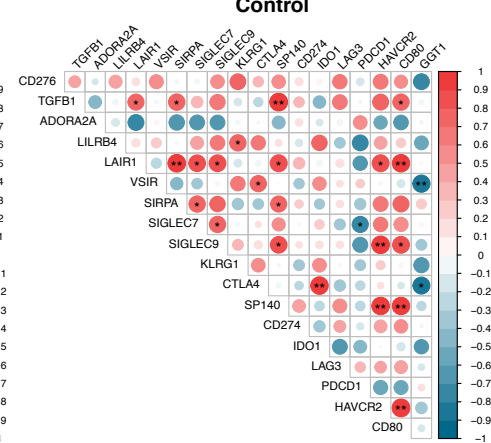

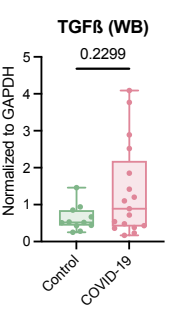

AG3 (RNAseq)
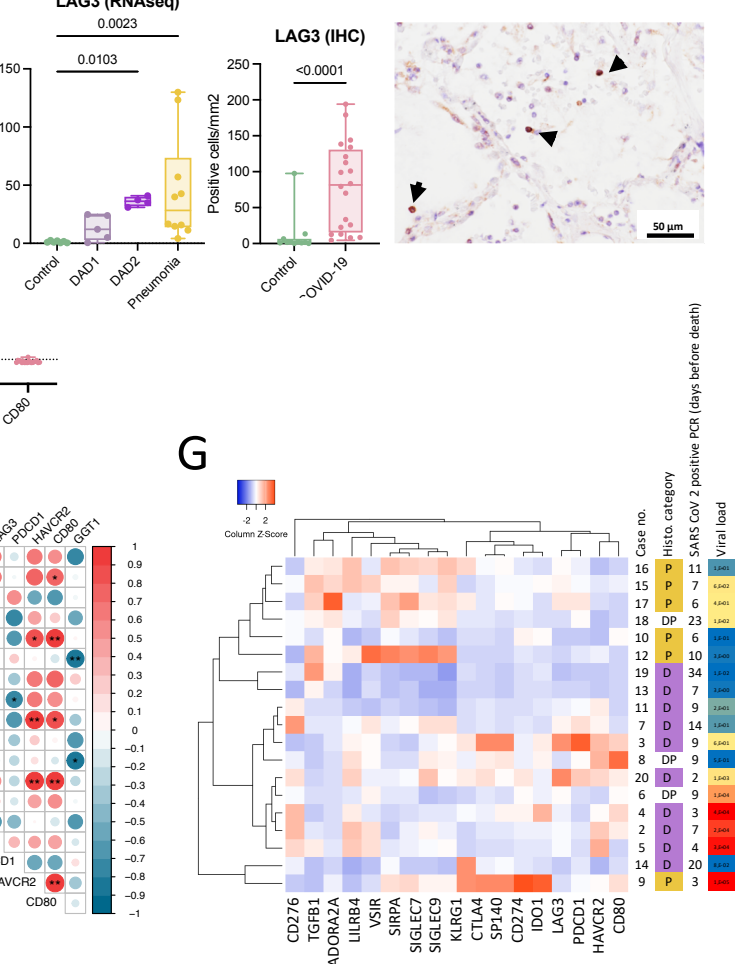

G

393 Figure 7. Signatures of immune-impairment in covid-19 lungs. (A) The tolerogenic leukocyte receptors LAIR-1 and LILRB4 are mainly induced in "DAD2" and "pneumonia" (Kruskal-Wallis test). (B) Spearman correlation of RNA expression of LAIR-1 and LILRB4 with C1q chains and induced collagen types (Spearman $R ; p^{*}<0.05$ to $p^{* * *<0.001)}$. (C) Significant induction of TGF $\beta 1$ transcription (Kruskal-Wallis test). Protein measurement by immunohistochemistry and Western blotting does not show a significant difference of covid-19 lungs to controls (Mann-Whitney test). (D) Strong induction of immune checkpoint inhibitors in covid-19 (order according to z-score). (E) LAG3 transcriptional induction (Kruskal-Wallis test) and increased lymphocyte staining with immunohistochemistry in covid-19 lung tissue (Mann-Whitney test). (F) Simultaneous transcriptional induction of immune checkpoint inhibitors in covid-19 lungs compared to controls (Pearson correlation; $p^{*}<0.05, p^{* * *}<0.001$ ). (E) Hierarchical clustering 
medRxiv preprint doi: https://doi.org/10.1101/2022.02.18.22270995; this version posted February 19, 2022. The copyright holder for this preprint (which was not certified by peer review) is the author/funder, who has granted medRxiv a license to display the preprint in

It is made available under a CC-BY-ND 4.0 International license .

404

405

406

407

408

409

410

411

412

413

414

415

416

417

418

419

420

421

422

423

424

425

426

427

428

429

of immune checkpoint inhibitors of covid-19 cases shows a separate grouping of samples with high viral loads (transcript abundance) versus samples with the histological pneumonia category (clustering: average linkage; distance measure: Pearson).

Since the development of secondary infections is likely driven by local immune-impairment we screened for other anti-inflammatory markers. TGF- $\beta 1$ is a key factor in the development and healing response of $A L I$ and also implicated in covid-19 lung pathology [40, 41]. TGF-61 transcription was significantly increased in covid-19, showing a huge variability, however, TGF$\beta 1$ protein measured by immunohistochemistry and western blotting showed no significant induction compared to controls (Figures 7C and S14). Since several immune and non-immune cell types are able to produce TGF- $\beta 1$, the observed variability in expression might reflect the temporal heterogeneity of lung pathologies in our cohort. Induction of certain inhibitory immune-checkpoints is reported in covid-19 [42-46]. We confirmed transcriptional induction of several inhibitory immune-checkpoints in covid-19 lungs (LAG3, PDCD1, ADORA2A, VSIR, CTLA4, SIRPA, LAIR1, SIGLEC9, LILRB4, SIGLEC7, HAVCR2), whereas some showed no induction (CD276, SP140, IDO1, KLRG1, CD274) or were even reduced (GGT1, CD80) compared to controls (Figures 7D and S15). Noteworthy, the top induced inhibitory immune-checkpoint was found to be LAG3 (lymphocyte-activation gene 3; syn.: CD223), dominantly induced in "DAD2" and "pneumonia" based on RNAseq, which was also confirmed by immunohistochemistry wherein mainly lymphocytes showed strong staining signals (Figures 7E and S16). LAG3 was recently described as a major increased factor in a plasma proteomic study of severe covid-19 [47]. During immune exhaustion multiple inhibitory receptors act often in synergy amplifying immune impairment, like LAG3 and PD-1 co-induced during chronic viral infections [48]. We confirmed synergistic induction of several inhibitory immunecheckpoints in covid-19 lungs, which showed a different costimulatory pattern compared to controls (Figure 7F). Interestingly, co-expression patterns discriminated cases with high viral 
medRxiv preprint doi: https://doi.org/10.1101/2022.02.18.22270995; this version posted February 19, 2022. The copyright holder for this preprint (which was not certified by peer review) is the author/funder, who has granted medRxiv a license to display the preprint in It is made available under a CC-BY-ND 4.0 International license .

loads (KLRG1, CTLA4, SP140, CD274, IDO1, LAG3, PDCD1, HAVCR2, CD80) from samples with pneumonia (CD276, TGFB1, ADORA2A, LILRB4, LAIR1, VSIR, SIRPA, SIGLEC7, SIGLEC9) suggesting a divergent pattern of induction of inhibitory immune-checkpoints during the course of covid-19 lung pathology (Figure 7G). In summary, these data highlight that multiple

434 pillars of immune impairment act in severe covid-19, leading to a reduced antimicrobial defense in lungs driving the development of secondary infections. The molecular dissection of cell types and immune inhibitory signals might enable the development of specific measures counteracting this potentially lethal complication.

\section{Discussion}

We performed a systematic autopsy study of 20 consecutive covid-19 cases and 14 controls to gain unbiased information about lethal disease courses from the early pandemic. and microbial factors involved in the development of secondary infections as a major sequel tempting to gain relevant pathophysiological insights from a newly emerging disease. Viral genotyping facilitated directly from autopsy material provided epidemiologic clues about

transmission and captured already early events of viral genetic adaptation. Noteworthy, a significant proportion of corpses yielded cultiviable SARS-CoV-2 indicating that autopsy might facilitate virus spread and that special safety requirements should be applied during postmortem examinations of covid-19 patients [49]. Our investigation showed that covid-19 lung pathology is multifaceted and that a major discriminator of lethal courses is DAD and the presence of secondary infections. This was evident by histology but also mirrored by the deep 
medRxiv preprint doi: https://doi.org/10.1101/2022.02.18.22270995; this version posted February 19, 2022. The copyright holder for this preprint (which was not certified by peer review) is the author/funder, who has granted medRxiv a license to display the preprint in It is made available under a CC-BY-ND 4.0 International license .

454 to $42 \%$ of patients with covid-19 [7]. Notably, DAD caused by the virus itself and secondary

455 infections are chronologically divergent and provoke overtly different host reactions.

456 Noteworthy, SARS-CoV-2 infection alone might not trigger prominent neutrophil recruitment

457 to the lung at all and neutrophil signatures found in recent covid-19 studies might likely

458 already indicate secondary infections $[15,18,31,50,51]$. Thus, it is important to seek for a

459 proper pre-classification of tissue samples based on histology to omit wrong conclusions in

460 omics-based analyses.

461 The resident lung microbiome is a relevant factor in the pathogenesis of lung infections

462 and reported to be altered in sepsis and $\operatorname{DAD}[9,10]$. Secondary lung infections are also a

463 complication in influenza, SARS and MERS, wherein bacteria like S. aureus or Klebsiella spp.

464 and fungi like Candida or Aspergillus spp. are emerging [13, 14]. Such microbial agents were

465 also prevalent in our cohort. Curiously, the mechanistic understanding why secondary

466 infections develop on top of viral infections is still limited. We could not identify any associated

467 clinical parameter clearly correlated with secondary infections but showed that lung immunity

468 is impaired in covid-19, which might drive these infections. This finding was also underscored

469 by the presence of polymicrobial infections and EBV indicative for a general decreased

470 immunity [12]. Immune exhaustion seems to follow the systemic immune hyperactivation in

471 severe covid-19 and myeloid cells, which are important for the recognition of virus infected

472 cells seem to be key for initiating the proinflammatory response $[52,53]$. Recent single-cell

473 transcriptomic studies of covid-19 patients identified myeloid cells as a major induced cell

474 type in BALF specimens with high proportions of proinflammatory macrophages $[15,50]$.

475 Generally, M1-type macrophages dominate early DAD, whereas later DAD stages show

476 increased M2-types involved in tissue repair with immunosuppressive features [23]. Thus,

477 later (organizing) phases of DAD might be specifically prone to acquire secondary infections. 
medRxiv preprint doi: https://doi.org/10.1101/2022.02.18.22270995; this version posted February 19, 2022. The copyright holder for this preprint (which was not certified by peer review) is the author/funder, who has granted medRxiv a license to display the preprint in It is made available under a CC-BY-ND 4.0 International license .

478 Respiratory failure in covid-19 is linked to strong complement activation [27, 28, 54]. Extensive

479 deposition of complement factors, including C1q, in vessels and epithelial cells of lungs and

480 skin was reported in covid-19 [55, 56]. Notably, the SARS-CoV-2 spike-protein might directly

481 activate complement via the alternative pathway [57]. Complement in covid-19 is currently

482 discussed mainly in the context of endothelial injury and fibrin-clot formation [29]. Our study

483 suggests another pathophysiological role, wherein $\mathrm{C} 1 \mathrm{q}$ and macrophages might perpetuate

484 immune impairment. Immune complexes formed by viral antigens and antibodies can activate

485 factor C1 as shown in SARS-CoV infection [58]. C1q is involved in the clearance of apoptotic

486 and necrotic cells by phagocytes, a process termed efferocytosis [59]. Apoptosis and necrosis

487 are prominent in covid-19 lungs [33, 34, 47]. During efferocytosis suppression of

488 overwhelming inflammation is important and phagocytes involved in this process are

489 producing anti-inflammatory cytokines. Therefore, C1q binds to molecules released from

490 apoptotic and necrotic cells (e.g. phosphatidylserine, nucleic acids, etc.) and these complexes

491 are recognized by receptors present on phagocytes, like LAIR-1, conferring uptake and

492 inducing a tolerogenic state [30, 35-37]. Noteworthy, binding of C1q to LAIR-1 on plasmacytoid

493 DCs restricts the production of type I interferons impairing antiviral defense, which also occurs

494 in covid-19 [36, 39]. The "DAD2" subtype in our study shows increased macrophages, C1q and

495 LAIR-1 and might therefore represent cases with a lowered immune tone prone for the 496 development of secondary infections. Overall the progression of early (exudative) DAD into

497 late (fibrotic) DAD indicates healing of ALI characterized by significant connective tissue remodeling and a reduced inflammatory tone $[60,61]$. Immune suppressive factors such as TGF- $\beta 1$ are known to be involved in this process and also LAIR-1 and LILRB4 recognizing 500 collagens or collagen-like proteins might act anti-inflammatory during this disease phase [39,

501 62-65]. Moreover, the synergistic induction of several tolerogenic factors including inhibitory 
medRxiv preprint doi: https://doi.org/10.1101/2022.02.18.22270995; this version posted February 19, 2022. The copyright holder for this preprint (which was not certified by peer review) is the author/funder, who has granted medRxiv a license to display the preprint in It is made available under a CC-BY-ND 4.0 International license .

immune-checkpoints $[42-47,66]$ and increased (apoptotic) cell death of immune-cells $[67,68]$

503 altogether perpetuate immune failure in covid-19.

The limitations of our descriptive study are that causalities cannot be directly inferred

and that the relatively small cohort cannot show the entire picture of severe covid-19 and associated secondary infections. Varying clinical courses and different comorbidities might also have influenced our findings. In addition, treatment of covid-19 has changed since the early pandemic, thus, current severe courses and developing sequels might also have

510 just a spectrum of pathophysiological states or are specific pathotypes. Moreover, post511 mortem effects like RNA degradation might have introduced additional noise in our 512 investigation. Nevertheless, we found autopsy complemented with microbiology and 513 molecular measures as a powerful tool to gain relevant clues about covid-19 pathophysiology.

514 Importantly, there exists an obvious knowledge gap in the understanding of the molecular 515 mechanisms driving the development of secondary infections on top of in viral lung diseases.

516 This should initiate further studies to understand the molecular pathways in more detail and

517 to unravel chronological phases of immuno-suppression which could also lead to development 518 of rational therapies counteracting this sequel not only in covid-19. For these investigations, 519 autopsy specimens and associated molecular data might serve as a valuable resource.

\section{Autopsy procedure \& specimen collection}

523 Autopsies were performed according to CDC guidelines 524 (https://www.cdc.gov/coronavirus/2019-ncov/hcp/guidance-postmortem-specimens.html) 525 and the epidemic response plan of the county of Styria in a BSL-3 facility that has been 526 specifically designed for post-mortem examinations and sample collection [49]. Full autopsies 527 were performed and swabs (eSwab, Copan), tissue and body fluid samples were taken. Tissues 528 were immediately fixed in $10 \%$ buffered formalin (for histology) or $2,5 \%$ buffered (sodium 
medRxiv preprint doi: https://doi.org/10.1101/2022.02.18.22270995; this version posted February 19, 2022. The copyright holder for this preprint (which was not certified by peer review) is the author/funder, who has granted medRxiv a license to display the preprint in

It is made available under a CC-BY-ND 4.0 International license .

529 cacodylate; pH 6.5; Sigma) glutaraldehyde (for electron microscopy), snap frozen in liquid 530 nitrogen or preserved in RNAlater (ThermoFisher) and stored at $-80^{\circ} \mathrm{C}$ until further processing.

\section{Histopathology and immunohistochemistry}

533 Formalin-fixed paraffin-embedded (FFPE) tissue specimens were processed and stained 534 according to standard procedures. Stains consisted of hematoxylin \& eosin (H\&E), periodic acid-Schiff (PAS), chromotrope aniline blue (CAB), sirius red, Gomori, Prussian blue, Giemsa and toluidine blue. Chronic renal changes involving the individual renal compartments were scored according to Sethi et al. [69]. Liver fibrosis was scored according to Ishak et al [70]. The following antibodies were used: Anti-SARS-CoV-2 nucleoprotein (NP) antibody (clone ID: 019, dilution 1:100, rabbit IgG; Sino Biological, Beijing; detection-system: Dako REAL TM EnVision TM HRP rabbit/mouse Dako K5007); CD68 (Ventana anti-CD68 (KP-1) monoclonal mouse 7902931; detection-system: Ventana Ultra View DAB); TTF1 (Cell marque 343M-96 Clone 8G7G3/1 monoclonal mouse 1:200; detection-system: Dako K5007); TGFß1 (Santacruz polyclonal rabbit AB; clone SC-146 1:50; detection-system: Ventana Ultra View DAB); LAG3 (Abcam polyclonal rabbit; clone ab180187 1:5000; detection-system: Dako K5007); C1q (Dako polyclonal rabbit, clone A0136 1:5000; detection-system: Dako K5007); CD163 (Ventana monoclonal mouse, clone MRQ-26 1:50; detection-system: Ventana Ultra View DAB). RNA insitu hybridization for EBV was performed with the Inform EBER Epstein Barr Virus early RNA kit (Ventana 800-2824) and the detection-system ISH invers blue (Ventana).

\section{Scoring of histological lung features}

\section{1}

From each case multiple specimens from each lobe were taken to account for variations in disease representation (at least 2 specimens per lobe corresponding to 10 specimens per case at least, mean: 13, range: 10-21) and assessed for histopathological features. Features were grouped according to (a) early (exudative) and (b) late (fibrotic) DAD as well as (c) general cellular and tissue reactions in pulmonary pathology and DAD development [21] and consisted of: Interstitial edema/thickening of the alveolo-capillary membranes (non-fibrotic); alveolar edema; hyaline membranes; intra-alveolar (loose) fibrin; scaled of pneumocytes; intraalveolar proliferation of pneumocytes; alveolar septal fibrosis (early stage organizing DAD); alveolar septal fibrosis (end stage organizing DAD); bronchialisation; squamous metaplasia; virus induced cellular changes in pneumocytes and/or alveolar macrophages; alveolar hemorrhage; interstitial hemorrhage; interstitial hemosidern (free); alveolar hemosiderin (siderophages); fibrin thrombi (capillaries); fibrin thrombi (larger vessels); vascular remodeling (increased density, vascular fissures); intra-alveolar macrophage accumulation; lymphocytes (within alveolo-capillary membranes); lymphocytes (within interstitial space); intra-alveolar (fibro-) cellular infiltrate; lymphocytes (alveolar); megakaryocytes (capillaries); alveolar neutrophils; bronchial neutrophils; a 4-grade scoring system was used to describe the severity of the different pathological features. Score 0 (feature absent), score 1 (feature present in $<=33 \%$ ), score 2 (feature present in $<=66 \%$ ), score 3 (feature present in $>66 \%$ ). Scores per slides were summed up and a final score (mean value) was calculated.

\section{Microbial culture and identification}

Native lung tissues were transferred into mixing vessels (ProbeAX; AxonLab) containing $5 \mathrm{ml}$ of physiological saline and were homogenized using a dispersion instrument (ULTRA-TURRAX ${ }^{\circledR}$ Tube Drive; AxonLab). The homogenates were inoculated ( $0.1 \mathrm{ml}$ aliquots) onto aerobic blood agar, MacConkey agar, chocolate agar, and anaerobic blood agar (BD Diagnostic) and into thioglycollate broth (Oxoid). Plates were incubated at $35^{\circ} \mathrm{C}$ and $37^{\circ} \mathrm{C}$ aerobically, in an 
medRxiv preprint doi: https://doi.org/10.1101/2022.02.18.22270995; this version posted February 19, 2022. The copyright holder for this preprint (which was not certified by peer review) is the author/funder, who has granted medRxiv a license to display the preprint in

It is made available under a CC-BY-ND 4.0 International license .

577 atmosphere containing $5 \%$ carbon dioxide and anaerobically (Genbox anaer, bioMérieux) for 578 up to 14 days, respectively. Cloudy thioglycollate broths were sub-cultured on plates. Colonies 579 were identified using matrix-assisted-laser-desorption-ionization time-of-flight mass580 spectrometry (MALDI-TOF MS; Vitek ${ }^{\circledR}$ MS, bioMérieux or MALDI Biotyper ${ }^{\mathrm{TM}}$, Bruker) or $16 \mathrm{~S}$ 581 rRNA gene sequencing [71].

582

583

584

\section{Virus isolation}

Lung tissues and swabs from lung parenchyma were used for cultivation of SARS-CoV-2 (Table $\mathrm{S} 3)$. After mechanical disruption samples were frozen $\left(-80^{\circ} \mathrm{C}\right)$ and thawed $\left(37^{\circ} \mathrm{C}\right)$ twice to increase cell lysis and viral release. $2 \mathrm{~mL}$ OptiPro SFM medium (Gibco) with $4 \mathrm{mM} \mathrm{L-Glutamine}$

587 (Gibco) and $1 \%$ penicillin-streptomycin $(10,000 \mathrm{U} / \mathrm{ml}$; Gibco) were added to the samples. After centrifugation (10 min., $1500 \mathrm{rcf}$ ) the supernatants were filtered through a $0.45 \mu \mathrm{m}$ membrane filter (Millipore) and inoculated on Vero CCL-81 cells with OptiPro SFM medium with $4 \mathrm{mM} \mathrm{L-}$ Glutamine and 1\% penicillin-streptomycin in T25 flasks (ThermoFisher). After 3-4 days incubation at $37^{\circ} \mathrm{C}$ and $5 \% \mathrm{CO} 2$, the whole cells were mechanically detached with cell scrapers and passaged including the supernatant on to new Vero CCL-81 cells growing in T75 flasks (ThermoFisher). After 1 week the cells were harvested and supernatants were stored after centrifugation (10min., $1500 \mathrm{rcf}$ ) at $-80^{\circ} \mathrm{C}$. Viral load was determined by qRT-PCR as described below.

\section{RNA extraction}

Samples consisted of swabs (eSWAB, Copan), tissues and body fluids, the latter were collected with sterile syringes. Fresh tissues were sampled directly into Magna Lyser Green Beads tubes (03358941001, Roche) pre-filled with $400 \mu l$ lysis buffer. Tissues were homogenized with a MagnaLyser (Roche) instrument using $6500 \mathrm{rpm}$ for $30 \mathrm{sec}$. and 3 repetitions. RNA was extracted from $200 \mu \mathrm{l}$ eSwab solution, $200 \mu \mathrm{l}$ liquid sample or tissue homogenate using the Maxwell 16 LEV simplyRNA Blood Kit (AS1310, Promega) according to the manufacturer's instructions. RNAs from VeroE6 cell cultures were isolated by using the QIAamp Viral RNA Mini Kit (Qiagen) without addition of carrier RNA and transcribed into cDNA with the High-Capacity cDNA Reverse Transcription Kit with RNase Inhibitor (Applied Biosystems) according to manufacturer's instructions.

\section{SARS-CoV-2 quantitative RT-PCR}

qRT-PCR was performed using a RdRP gene assay and with a probe specific to SARS-CoV-2 [72]. Briefly, primers, probes and $5 \mu$ l of RNA were added to $10 \mu$ l of SuperScript III One-Step RT-PCR System with Platinum Taq High Fidelity DNA Polymerase mastermix (ThermoFisher). PCR was performed on a Quantstudio 7 instrument (ThermoFisher) with the following cycling conditions: $55^{\circ} \mathrm{C}$ for $15 \mathrm{~min}, 95^{\circ} \mathrm{C}$ for $3 \mathrm{~min} ; 45$ cycles consisting of $95^{\circ} \mathrm{C}$ for $15 \mathrm{sec}$ and $58^{\circ} \mathrm{C}$ for $30 \mathrm{sec}$. Amplification data was downloaded and processed using the qpcR package of the $R$ project (https://www.r-project.org/). Amplification efficiency plots were visually inspected and Cp2D (cycle peak of second derivative) values were calculated for samples with valid amplification curves. Plots were generated with $\mathrm{R}$ using the reshape, tidyverse and ggplot packages. qRT-PCR of virus cultures employed primer sets recommended by the CDC detecting three different regions of the viral nucleocapsid (2019-nCoV N1-F 5'-GAC CCC AAA ATC AGC GAA AT-3', 2019-nCoV,_N1-R 5'-TCT GGT TAC TGC CAG TTG AAT CTG-3'; 2019-nCoV_N2-F 5'TTA CAA ACA TTG GCC GCA AA-3', 2019-nCoV_N2-R 5'-GCG CGA CAT TCC GAA GAA-3'; 2019- 
medRxiv preprint doi: https://doi.org/10.1101/2022.02.18.22270995; this version posted February 19, 2022. The copyright holder for this preprint (which was not certified by peer review) is the author/funder, who has granted medRxiv a license to display the preprint in

It is made available under a CC-BY-ND 4.0 International license .

625

626

627

628

629

630

631

632

633

634

635

636

637

638

639

640

641

642

643

644

645

646

647

648

649

650

651

652

653

654

655

656

657

658

659

660

661

662

663

664

665

666

667

668

669

670

671

672

AGC G-3', 2019-CoV_RP-R 5'-GAG CGG CTG TCT CCA CAA GT-3') or GAPDH (GAPDH_f 5'CCTCCACCTTTGACGCT-3', GAPDH_r 5'-TTGCTGTAGCCAAATTCGTT-3') as control. PCR was performed with the SYBR Green PCR Mastermix (Applied Biosystems) on a Quantstudio 7 instrument (ThermoFisher) with the following cycling conditions: $25^{\circ} \mathrm{C}$ for $2 \mathrm{~min}, 50^{\circ} \mathrm{C}$ for 15 min, $95^{\circ} \mathrm{C}$ for $10 \mathrm{~min}, 45 \mathrm{cycles}$ consisting of $95^{\circ} \mathrm{C}$ for $3 \mathrm{sec}$ and $55^{\circ} \mathrm{C}$ for $30 \mathrm{sec}$.

\section{Viral genome sequencing}

PCR primers spanning the whole genome of SARS-CoV-2 were designed yielding in about $2 \mathrm{~kb}$ amplicons (Table S9). $2.5 \mu \mathrm{l}$ of RNA were used in three separate RT-PCR reactions as described above with oligonucleotide primers at $400 \mathrm{nM}$ concentration with the following cycling conditions: $55^{\circ} \mathrm{C}$ for $15 \mathrm{~min}, 95^{\circ} \mathrm{C}$ for $3 \mathrm{~min} ; 35 \mathrm{cycles}$ consisting of $95^{\circ} \mathrm{C}$ for $15 \mathrm{sec}$ and $57^{\circ} \mathrm{C}$ for $3 \mathrm{~min}$; final extension at $72^{\circ} \mathrm{C}$ for $10 \mathrm{~min}$. PCR products were combined and purified by incubation with 1.8X Ampure XT beads (Beckman Coulter) followed by two washes with $75 \%$ ethanol and elution in $30 \mu \mathrm{l}$ water. Amplicons were fragmented to $150-250 \mathrm{bp}$ length and Ion Torrent barcode and sequencing adapters were ligated to the fragments using the NEBNext Fast DNA Fragmentation \& Library Prep Set for Ion Torren kit (New England Biolabs) according to the manufacturer's recommendations. Libraries were sequenced on an Ion Torrent S5XL instrument using a 540 Chip Kit and the $200 \mathrm{bp}$ sequencing kit (ThermoFisher). Sequences were aligned to the SARS-CoV-2 reference genome (acc. no.: NC_045512.2) using TMAP (v5.10.11) and variants were called with the Torrent Variant Caller (v5.10-12). All called variants were visually inspected and consensus sequences of the viral genomes were generated with bcftools (v1.3.1). Consensus sequences were aligned using clustalw (v2.1), guide trees were visualized in figtree (v1.4.4) and final adjustments were made with Incscape (v0.92). SARSCoV-2 genomes from our study were uploaded and analyzed with the GISAID SARS-CoV-2 (hCoV-19) database which can be accessed via https://www.gisaid.org/epifluapplications/next-hcov-19-app/ [73, 74].

\section{RNA sequencing}

Libraries for RNA sequencing (RNAseq) from lung tissues (19 covid-19 cases \#2-\#20 and 7 control cases \#21, \#23-\#28) were prepped with the KAPA RNA HyperPrep Kit with RiboErase (HMR) for Illumina ${ }^{\circledR}$ platforms (KAPABIOSYSTEMS) according to the manufacturers protocol. Slight modifications from the protocol consisted of a fragmentation step at $65^{\circ} \mathrm{C}$ for $1 \mathrm{~min}, 12$ cycles of PCR, as well as an additional bead cleanup at the end of the prep. Libraries were pooled in two pools of 13 samples each by concentration measured with Qubit (ThermoFisher), followed by a bead-cleanup step and an additional QC with Qubit (ThermoFisher) and BioAnalyzer (Agilent). Sequences were resolved on a NovaSeq 6000 Sequencer (Illumina) with a standard paired-end protocol. RNAseq data were aligned to the human reference genome using STAR [75] (GRCh38 assembly, Ensembl V99 gene models) in 2-pass mode with the following parameters: -sjdbOverhang 100 -outFilterMultimapNmax 20 -outFilterMismatchNoverLmax 0.05 -outFilterScoreMin 0 -outFilterScoreMinOverLread 0 outSJfilterReads Unique -outSJfilterOverhangMin 2015151515 -outSJfilterCountUniqueMin

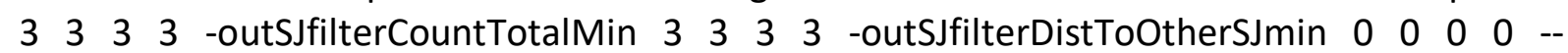
outSJfilterIntronMaxVsReadN 100000 -alignIntronMin 20 -alignIntronMax 100000 -alignMatesGapMax 100000 -alignSJoverhangMin 12 -alignSJstitchMismatchNmax 5 -1 55 alignSJDBoverhangMin 7 -alignSplicedMateMapLmin 0 -alignSplicedMateMapLminOverLmate 0.5 -limitSjdbInsertNsj 5000000 -clip3pAdapterMMp 0.5 -outSAMmultNmax 1 outSAMmapqUnique 60 -outFilterType BySJout -outSAMunmapped Within -outWigType bedGraph -outReadsUnmapped None SortedByCoordinate -outSAMattrlHstart 1 - 
medRxiv preprint doi: https://doi.org/10.1101/2022.02.18.22270995; this version posted February 19, 2022. The copyright holder for this preprint (which was not certified by peer review) is the author/funder, who has granted medRxiv a license to display the preprint in

It is made available under a CC-BY-ND 4.0 International license .

673 twopassMode Basic -chimSegmentMin 8 -chimOutType Junctions WithinBAM SoftClip 674 chimScoreMin 1 -chimScoreDropMax 20 -chimJunctionOverhangMin 8 675 chimSegmentReadGapMax 3 -quantMode GeneCounts -outSAMstrandField intronMotif 676 outFilterlntronStrands None -chimMainSegmentMultNmax 2 -outSAMattributes NH HI AS nM 677 NM MD jM jI XS ch. Alignment to the virus genome reference NC_045512.2 was performed 678 using bowtie2-2.4.1 [76] on all reads that did not map to the human genome. Read counts on 679 plus-/minus-strand were counted using custom python scripts. Exact positioning of the reads 680 on plus-/minus-strand was done splitting the bam files aligned to NC_045512.2 using samtools 681 -f $0 \times 10$ and samtools $-F$ 0x10 (v0.1.19-44428cd) and bedtools genomecov -ibam BAM 682 NC_045512.2 -d (bedtools v2.17.0).

683

684

\section{RNA profiling}

685

Gene counts were determined using HTSeq (v0.12.4) and normalized as fragments per kilobase per million (FPKM) after TMM correction. Gene set variation analysis (GSVA) was performed against a set of immune signatures with xCell [19] and means were calculated per cell type using custom R-scripts. Graphs and analyses were generated using R-3.6.0. Differential gene expression was conducted using edgeR 690 (https://doi.org/doi:10.18129/B9.bioc.edgeR) [77]. Differentially expressed genes were 691 selected with $F D R<0.05, \log C P M>1$, and $F P K M>1$ in at least 5 samples. Clustering of differentially expressed genes was performed using hclust hierachical clustering and subsequent cutting of the gene tree at $R$ function cutree with $h=0.25$. Gene set enrichment analysis for clusters was done using the online tool (https://www.gseamsigdb.org/gsea/msigdb/annotate.jsp) [78] for canonical pathways and FDR<0.05.

\section{Single cell transcriptomic metanalysis}

Selected genes from single-cell transcriptomic metadata from Xu et al [31] and Delorey et al [17] were analyzed with the single-cell atlas database SCovid [79].

700

\section{Microbiome analysis based on RNAseq}

702 Microbiome analysis was performed with the following steps using all reads from STAR alignment not mapping to the human reference: quality filtering using fastx $-q 30-p 26-Q 33$ (v0.0.13, http://hannonlab.cshl.edu/fastx_toolkit/), cleaning of the fasta file using seqcleanx86_64 -N -M -A (https://sourceforge.net/projects/seqclean/), realigning to the human reference using blastn against all databases and removal of all reads with $94 \%$ similarity. Remaining reads were annotated using MetaPhIAn2 (v2.6.0) [80] and Pathseq (GATK v4.1.0.0) [81] with default settings.

\section{Microbiome analysis based on the 16S rRNA gene and internal transcribed spacers (ITS)} from FFPE samples which enabled us to preselect samples based on histology showing unambiguous pathology (i.e. DAD vs. pneumonia). DNA was extracted from FFPE tissues using the Maxwell 16 Tissue DNA Purification Kit (Promega). DNA concentration was measured by Picogreen fluorescence. The variable V1-V2 region of the bacterial 16S rRNA gene was amplified with PCR from 50ng DNA using oligonucleotide primers 16s_515_S3_fwd: 5'TGCCAGCAGCCGCGGTAA-3' and 16s_806_S2_rev: 5'-GGACTACCAGGGTATCTAAT-3'. This 16S rDNA region was chosen since it gives robust taxonomic classification and has been shown to be suitable for community clustering. Likewise, fungal ITS sequence was amplified with 
medRxiv preprint doi: https://doi.org/10.1101/2022.02.18.22270995; this version posted February 19, 2022. The copyright holder for this preprint (which was not certified by peer review) is the author/funder, who has granted medRxiv a license to display the preprint in

It is made available under a CC-BY-ND 4.0 International license .

721 was amplified with the 16s Complete PCR Mastermix Kit (Molzym). The first PCR reaction product was subjected to a second round of PCR with primers fusing the 16s/ITS primer sequence to the $A$ and $P$ adapters necessary for lon Torrent sequencing while additionally including a molecular barcode sequence to allow multiplexing of up to 96 samples simultaneously. PCR products were subjected to agarose gel electrophoresis and the band of the expected length (330nt) was excised from the gel and purified using the QiaQick (Qiagen) gel extraction system. DNA concentration of the final PCR product was measured by Picogreen fluorescence. Amplicons from up to 60 samples were pooled equimolarly and sequencing was performed on Ion Torrent XL benchtop sequencer using the Ion 400BP Sequencing chemistry (all reagents from ThermoFisher). Sequences were split by barcode and transferred to the Torrent suite server.

Raw bam-files comprised of single-end reads generated by NGS, were converted from bam files to fastq.gz files by using samtools (http://www.htslib.org/). Quality control and preprocessing of sequences was performed using FastQC (version 0.7), MultiQC (version 1.7) and trimmomatic (version 0.36.5) using following parameters: LEADING:3 TRAILING:3 SLIDINGWINDOW:4:15 MINLEN:200. Sequence processing and microbiome analysis was performed using QIIME2 (version 2020.6) [82]. After quality filtering all samples with less than 9833 reads/samples were excluded from downstream analysis. In concordance with RNA-Seq analysis Covid-1 was excluded for sub-analysis (Cause of Death: Myocardial Infarction), resulting in 18 Covid and 12 control samples for 16S analysis (Average frequency: 28201.7 reads/sample). For ITS analysis only 1 sample showed more than 9833 reads/per sample (Covid-18: 10272 reads). All other samples showed no clear ITS signal with a sequencing depth of maximum 219 reads per sample. Denoising, dereplication and chimera filtering of singleend reads were performed using DADA2 (denoise-pyro) [83]. 16S-based analysis was performed with the latest SILVA 138 taxonomy and the Naive Bayes classifier trained on Silva 138 99\% OTUs full-length sequences. For ITS-based analysis a classifier was trained on the UNITE reference database (ver8-99-classifier; 04.02.2020) according to John Quensen (http://john-quensen.com/tutorials/training-the-qiime2-classifier-with-unite-its-referencesequences/; assessed 20/08/2020). Differences in microbial composition between groups were tested with implemented QIIME2 plugins using PERMANOVA $(p<0.05$, qiime diversity beta-group-significance: Bray-Curtis, Jaccard, Unweighted UniFrac, Weighted UniFrac) and Kruskal-Wallis ( $p<0.05$, qiime diversity alpha-group-significance: Observed features, Shannon, Evenness, Faith PD). For metagenomic biomarker discovery taxonomic feature-tables were introduced to LEfSe (linear discriminant analysis effect size) method (Galaxy version 1.0; $\mathrm{p}<0.05$, LDA $>2$, All-against-all) [84]. Plots were generated with R (version 3.6.2)6 in RStudio (1.1.463)7 using following packages: tidyverse (1.3.0)8, qiime2r (0.99.6)9, ggplot2 (3.3.3)10, dplyr (1.0.6)11 and ggpubr (0.4.0.999)12 and GraphPad Prism. The graphical abstract was created with BioRender (www.BioRender.com).

\section{Protein isolation and western blot}

761 Proteins from lung tissues were extracted with TRIzol ${ }^{\circledR}$ (ThermoFisher) according to the 762 supplier's protocol. Briefly, tissue homogenates were subjected to phase separation wherein the organic phase containing the protein was further processed. Four volumes of ice-cold acetone were added to the organic phase and the mixture was incubated at $-20^{\circ} \mathrm{C}$ overnight, followed by a centrifugation step $(13000 \mathrm{rpm})$ at $4^{\circ} \mathrm{C}$ for $15 \mathrm{~min}$. The supernatant was discarded and the pellets were dried at $60^{\circ} \mathrm{C}$ for $60 \mathrm{~min}$. Subsequently $100 \mu$ I RIPA buffer (Sigma) containing protease inhibitors and phosphatase $(0.1 \mathrm{mM}$ Pefabloc, $1 \mathrm{mM}$ DTT, $1 \mathrm{X}$ cOmplete $^{\mathrm{TM}}$ Mini, $1 \mathrm{X}$ PhosSTOP ${ }^{\mathrm{TM}}$ ) and $1 \%$ SDS (Roche) were added and the mixture 
medRxiv preprint doi: https://doi.org/10.1101/2022.02.18.22270995; this version posted February 19, 2022. The copyright holder for this preprint (which was not certified by peer review) is the author/funder, who has granted medRxiv a license to display the preprint in

It is made available under a CC-BY-ND 4.0 International license.

incubated at $65^{\circ} \mathrm{C}$ for 90 min. Supernatants were transferred to a new Eppendorf tube and $100 \mu \mathrm{l} 8 \mathrm{M}$ urea in $0.05 \mathrm{M}$ Tris $(\mathrm{pH} \mathrm{8,5})$ and $1 \%$ SDS were added and incubated at $55^{\circ} \mathrm{C}$ for 30 min. Corresponding supernatants and pellets were pooled and transferred to $2 \mathrm{ml}$ MagNA Lyser tubes (Roche) with ceramic beads and homogenized 2 times at $6500 \mathrm{rpm}$ for $20 \mathrm{sec}$. Samples were incubated on ice for $10 \mathrm{~min}$ and subsequently centrifugated with $13000 \mathrm{rpm}$ at $4^{\circ} \mathrm{C}$ for $15 \mathrm{~min}$. Supernatants were transferred to new Eppendorf tubes. For western blotting proteins were mixed with $4 \mathrm{X}$ Laemmli buffer (Bio-Rad) and incubated for $10 \mathrm{~min}$ at $95^{\circ} \mathrm{C}$ and then loaded onto 11\% (v/v) SDS-PAGE gels (Amersham) and electrophoresed at $80 \mathrm{~mA}$ for $2 \mathrm{~h}$ and subsequently transferred onto nitrocellulose membranes (Amersham). Blotting efficiency was determined with Ponceau staining (Ponceau S solution, Sigma). Non-specific binding was blocked with $5 \%(\mathrm{w} / \mathrm{v})$ non-fat dry milk (Bio-Rad) in TRIS-buffered saline and $0.1 \%(\mathrm{v} / \mathrm{v})$ Tween 20 (Merck) for $1 \mathrm{~h}$. Subsequently, the membranes were incubated with antibodies against $\mathrm{C} 1 \mathrm{q}$ (Dako Denmark A/S 1:5000), TGFß1 (Cell Signaling Technology, 1:1000), and GAPDH (Cell Signaling Technology, 1:1000) overnight at $4^{\circ} \mathrm{C}$. Thereafter, membranes were washed and incubated with the appropriate HRP-conjugated secondary antibody (Amersham, ECL AntiRabbit IgG, 1:5000). Immunolabeling was detected using ECL Select Western Blot Reagent (Amersham) and visualized with the ImageQuant ${ }^{\mathrm{TM}}$ LAS 500 (Amersham). GAPDH was used as loading control to determine protein abundance and band density was quantified and compared by using ImageJ.

\section{Ethics statement}

The study was approved by the ethics committee of the Medical University of Graz (EKnumber: 32-362 ex 19/20).

\section{Data availability}

The sequencing data has been deposited in ENA under the acc. no. PRJEB45873.

\section{Acknowledgements}

We are grateful to Tanja V. Mascher, Birgit Gangl, Margit Gogg-Kamerer, Iris Kufferath, Sylvia Eidenhammer, Christine Langner, Stella Wolfgruber, Daniela Pabst, Helmut Donnerer and Lajos Redecsi for their technical assistance.

\section{Funding}

Supported from the Medical university of Graz and the Austrian Science fund (FWF, DK-MOLIN W1241). The design of the BSL-3 laboratory used for autopsy of covid-19 cases was supported by the EU-funded program "European Research Infrastructure for Highly Pathogenic Agents" (ERINHA-Advance, Grant agreement 824061).

\section{Author contributions}

Conceptualization and methodology, $\mathrm{MZ}, \mathrm{GG}, \mathrm{KK}, \mathrm{PR}, \mathrm{KZ}$. Investigation and formal analysis, $M Z, K K, P W, P R, M S, M N, S E, L M-M, G K, M L, A B, E L, A T$, EW, SS, M-JP, F-RV, CL, BJ, LO, GG. Resources, KZ, PR, GG, BT, HL. Writing of original draft GG. Writing, review and editing, all authors. Funding acquisition, KZ, GG, HL. Supervision, GG, PR, KZ. All authors have read and agreed to the published version of the manuscript. 
medRxiv preprint doi: https://doi.org/10.1101/2022.02.18.22270995; this version posted February 19, 2022. The copyright holder for this preprint (which was not certified by peer review) is the author/funder, who has granted medRxiv a license to display the preprint in

It is made available under a CC-BY-ND 4.0 International license .

References

816 1. Hou, Y.J., et al., SARS-CoV-2 Reverse Genetics Reveals a Variable Infection Gradient in

817

818

819

820

821

822

823

824

825

826

827

828

829

830

831

832

833

834

835

836

837

838

839

840

841

842

843

844

845

846

847

848

849

850

851

852

853

854

855

856

857

858

859

860

2. Ramlall, V., et al., Immune complement and coagulation dysfunction in adverse outcomes of SARS-CoV-2 infection. Nat Med, 2020. 26(10): p. 1609-1615.

3. Lowery, S.A., A. Sariol, and S. Perlman, Innate immune and inflammatory responses to SARS-CoV-2: Implications for COVID-19. Cell Host Microbe, 2021. 29(7): p. 10521062.

4. Blanco-Melo, D., et al., Imbalanced Host Response to SARS-CoV-2 Drives Development of COVID-19. Cell, 2020. 181(5): p. 1036-1045 e9.

5. Wang, T., et al., Single-cell RNA sequencing reveals the sustained immune cell dysfunction in the pathogenesis of sepsis secondary to bacterial pneumonia. Genomics, 2021. 113(3): p. 1219-1233.

6. Roquilly, A., et al., Alveolar macrophages are epigenetically altered after inflammation, leading to long-term lung immunoparalysis. Nat Immunol, 2020. 21(6):

7. Buehler, P.K., et al., Bacterial pulmonary superinfections are associated with longer duration of ventilation in critically ill COVID-19 patients. Cell Rep Med, 2021. 2(4): p. 100229.

8. Hou, Y.J., et al., SARS-CoV-2 D614G variant exhibits efficient replication ex vivo and transmission in vivo. Science, 2020. 370(6523): p. 1464-1468.

9. Luyt, C.E., et al., Pulmonary infections complicating ARDS. Intensive Care Med, 2020. 46(12): p. 2168-2183.

10. Dickson, R.P., et al., Enrichment of the lung microbiome with gut bacteria in sepsis and the acute respiratory distress syndrome. Nat Microbiol, 2016. 1(10): p. 16113.

11. Huffnagle, G.B., R.P. Dickson, and N.W. Lukacs, The respiratory tract microbiome and lung inflammation: a two-way street. Mucosal Immunol, 2017. 10(2): p. 299-306.

12. Tangye, S.G., U. Palendira, and E.S. Edwards, Human immunity against EBV-lessons from the clinic. J Exp Med, 2017. 214(2): p. 269-283.

13. Morens, D.M., J.K. Taubenberger, and A.S. Fauci, Predominant role of bacterial pneumonia as a cause of death in pandemic influenza: implications for pandemic influenza preparedness. J Infect Dis, 2008. 198(7): p. 962-70.

14. Klein, E.Y., et al., The frequency of influenza and bacterial coinfection: a systematic review and meta-analysis. Influenza Other Respir Viruses, 2016. 10(5): p. 394-403.

15. Liao, M., et al., Single-cell landscape of bronchoalveolar immune cells in patients with COVID-19. Nat Med, 2020. 26(6): p. 842-844.

16. $\mathrm{Wu}, \mathrm{M}$., et al., Transcriptional and proteomic insights into the host response in fatal COVID-19 cases. Proc Natl Acad Sci U S A, 2020. 117(45): p. 28336-28343.

17. Delorey, T.M., et al., COVID-19 tissue atlases reveal SARS-CoV-2 pathology and cellular targets. Nature, 2021. 595(7865): p. 107-113.

18. Nie, X., et al., Multi-organ proteomic landscape of COVID-19 autopsies. Cell, 2021. 184(3): p. 775-791 e14.

19. Aran, D., Z. Hu, and A.J. Butte, xCell: digitally portraying the tissue cellular heterogeneity landscape. Genome Biol, 2017. 18(1): p. 220.

20. Ackermann, M., et al., Pulmonary Vascular Endothelialitis, Thrombosis, and Angiogenesis in Covid-19. N Engl J Med, 2020. 383(2): p. 120-128. 
medRxiv preprint doi: https://doi.org/10.1101/2022.02.18.22270995; this version posted February 19, 2022. The copyright holder for this preprint (which was not certified by peer review) is the author/funder, who has granted medRxiv a license to display the preprint in

perpetuity.
It is made available under a CC-BY-ND 4.0 International license .

861

862

863

864

865

866

867

868

869

870

871

872

873

874

875

876

877

878

879

880

881

882

883

884

885

886

887

888

889

890

891

892

893

894

895

896

897

898

899

900

901

902

903

904

905

906

907

21. Hughes, K.T. and M.B. Beasley, Pulmonary Manifestations of Acute Lung Injury: More Than Just Diffuse Alveolar Damage. Arch Pathol Lab Med, 2017. 141(7): p. 916-922.

22. Chen, X., et al., Macrophage polarization and its role in the pathogenesis of acute lung injury/acute respiratory distress syndrome. Inflamm Res, 2020. 69(9): p. 883895.

23. Huang, X., et al., The Role of Macrophages in the Pathogenesis of ALI/ARDS. Mediators Inflamm, 2018. 2018: p. 1264913.

24. Fan, E.K.Y. and J. Fan, Regulation of alveolar macrophage death in acute lung inflammation. Respir Res, 2018. 19(1): p. 50.

25. Wang, C., et al., Alveolar macrophage dysfunction and cytokine storm in the pathogenesis of two severe COVID-19 patients. EBioMedicine, 2020. 57: p. 102833.

26. Liu, L., et al., Anti-spike IgG causes severe acute lung injury by skewing macrophage responses during acute SARS-CoV infection. JCI Insight, 2019. 4(4).

27. Holter, J.C., et al., Systemic complement activation is associated with respiratory failure in COVID-19 hospitalized patients. Proc Natl Acad Sci U S A, 2020. 117(40): p. 25018-25025.

28. Java, A., et al., The complement system in COVID-19: friend and foe? JCI Insight, 2020. 5(15).

29. Perico, L., et al., Immunity, endothelial injury and complement-induced coagulopathy in COVID-19. Nat Rev Nephrol, 2021. 17(1): p. 46-64.

30. Lu, J.H., et al., The classical and regulatory functions of $\mathrm{C} 1 \mathrm{q}$ in immunity and autoimmunity. Cell Mol Immunol, 2008. 5(1): p. 9-21.

31. $\mathrm{Xu}, \mathrm{G}$., et al., The differential immune responses to COVID-19 in peripheral and lung revealed by single-cell RNA sequencing. Cell Discov, 2020. 6: p. 73.

32. Carvelli, J., et al., Association of COVID-19 inflammation with activation of the C5aC5aR1 axis. Nature, 2020. 588(7836): p. 146-150.

33. Li, S., et al., SARS-CoV-2 triggers inflammatory responses and cell death through caspase-8 activation. Signal Transduct Target Ther, 2020. 5(1): p. 235.

34. Mulay, A., et al., SARS-CoV-2 infection of primary human lung epithelium for COVID19 modeling and drug discovery. Cell Rep, 2021. 35(5): p. 109055.

35. Bohlson, S.S., et al., Complement, c1q, and c1q-related molecules regulate macrophage polarization. Front Immunol, 2014. 5: p. 402.

36. Son, M., B. Diamond, and F. Santiago-Schwarz, Fundamental role of C1q in autoimmunity and inflammation. Immunol Res, 2015. 63(1-3): p. 101-6.

37. Thielens, N.M., et al., C1q: A fresh look upon an old molecule. Mol Immunol, 2017. 89: p. 73-83.

38. Lebbink, R.J., et al., Collagens are functional, high affinity ligands for the inhibitory immune receptor LAIR-1. J Exp Med, 2006. 203(6): p. 1419-25.

39. Son, M., et al., C1q limits dendritic cell differentiation and activation by engaging LAIR-1. Proc Natl Acad Sci U S A, 2012. 109(46): p. E3160-7.

40. Peters, D.M., et al., TGF-beta directs trafficking of the epithelial sodium channel ENaC which has implications for ion and fluid transport in acute lung injury. Proc Natl Acad Sci U S A, 2014. 111(3): p. E374-83.

41. Vaz de Paula, C.B., et al., COVID-19: Immunohistochemical Analysis of TGF-beta Signaling Pathways in Pulmonary Fibrosis. Int J Mol Sci, 2021. 23(1).

42. Files, J.K., et al., Sustained cellular immune dysregulation in individuals recovering from SARS-CoV-2 infection. J Clin Invest, 2021. 131(1). 
medRxiv preprint doi: https://doi.org/10.1101/2022.02.18.22270995; this version posted February 19, 2022. The copyright holder for this preprint (which was not certified by peer review) is the author/funder, who has granted medRxiv a license to display the preprint in

It is made available under a CC-BY-ND 4.0 International license.

908

909

910

911

912

913

914

915

916

917

918

919

920

921

922

923

924

925

926

927

928

929

930

931

932

933

934

935

936

937

938

939

940

941

942

943

944

945

946

947

948

949

950

951

952

953

954

955
43. Jeannet, R., et al., Severe COVID-19 is associated with deep and sustained multifaceted cellular immunosuppression. Intensive Care Med, 2020. 46(9): p. 17691771.

44. Li, M., et al., Elevated Exhaustion Levels of NK and CD8(+) T Cells as Indicators for Progression and Prognosis of COVID-19 Disease. Front Immunol, 2020. 11: p. 580237.

45. Bobcakova, A., et al., Immune Profile in Patients With COVID-19: Lymphocytes Exhaustion Markers in Relationship to Clinical Outcome. Front Cell Infect Microbiol, 2021. 11: p. 646688.

46. Diao, B., et al., Reduction and Functional Exhaustion of T Cells in Patients With Coronavirus Disease 2019 (COVID-19). Front Immunol, 2020. 11: p. 827.

47. Filbin, M.R., et al., Longitudinal proteomic analysis of severe COVID-19 reveals survival-associated signatures, tissue-specific cell death, and cell-cell interactions. Cell Rep Med, 2021. 2(5): p. 100287.

48. Blackburn, S.D., et al., Coregulation of $C D 8+T$ cell exhaustion by multiple inhibitory receptors during chronic viral infection. Nat Immunol, 2009. 10(1): p. 29-37.

49. Loibner, M., et al., Biosafety Requirements for Autopsies of Patients with COVID-19: Example of a BSL-3 Autopsy Facility Designed for Highly Pathogenic Agents. Pathobiology, 2021. 88(1): p. 37-45.

50. Melms, J.C., et al., A molecular single-cell lung atlas of lethal COVID-19. Nature, 2021. 595(7865): p. 114-119.

51. Wauters, E., et al., Discriminating mild from critical COVID-19 by innate and adaptive immune single-cell profiling of bronchoalveolar lavages. Cell Res, 2021. 31(3): p. 272290.

52. Merad, M. and J.C. Martin, Pathological inflammation in patients with COVID-19: a key role for monocytes and macrophages. Nat Rev Immunol, 2020. 20(6): p. 355-362.

53. McGonagle, D., et al., The Role of Cytokines including Interleukin-6 in COVID-19 induced Pneumonia and Macrophage Activation Syndrome-Like Disease. Autoimmun Rev, 2020. 19(6): p. 102537.

54. Messner, C.B., et al., Ultra-High-Throughput Clinical Proteomics Reveals Classifiers of COVID-19 Infection. Cell Syst, 2020. 11(1): p. 11-24 e4.

55. Magro, C., et al., Complement associated microvascular injury and thrombosis in the pathogenesis of severe COVID-19 infection: A report of five cases. Transl Res, 2020. 220: p. 1-13.

56. Macor, P., et al., Multiple-Organ Complement Deposition on Vascular Endothelium in COVID-19 Patients. Biomedicines, 2021. 9(8).

57. Yu, J., et al., Direct activation of the alternative complement pathway by SARS-CoV-2 spike proteins is blocked by factor D inhibition. Blood, 2020. 136(18): p. 2080-2089.

58. Yang, Y.H., et al., Autoantibodies against human epithelial cells and endothelial cells after severe acute respiratory syndrome (SARS)-associated coronavirus infection. J Med Virol, 2005. 77(1): p. 1-7.

59. Doran, A.C., A. Yurdagul, Jr., and I. Tabas, Efferocytosis in health and disease. Nat Rev Immunol, 2020. 20(4): p. 254-267.

60. Matthay, M.A., et al., Acute respiratory distress syndrome. Nat Rev Dis Primers, 2019. 5(1): p. 18.

61. Margaroli, C., et al., Spatial mapping of SARS-CoV-2 and H1N1 lung injury identifies differential transcriptional signatures. Cell Rep Med, 2021. 2(4): p. 100242.

62. Fernandez, I.E. and O. Eickelberg, The impact of TGF-beta on lung fibrosis: from targeting to biomarkers. Proc Am Thorac Soc, 2012. 9(3): p. 111-6. 
medRxiv preprint doi: https://doi.org/10.1101/2022.02.18.22270995; this version posted February 19, 2022. The copyright holder for this preprint (which was not certified by peer review) is the author/funder, who has granted medRxiv a license to display the preprint in

It is made available under a CC-BY-ND 4.0 International license.

956

957

958

959

960

961

962

963

964

965

966

967

968

969

970

971

972

973

974

975

976

977

978

979

980

981

982

983

984

985

986

987

988

989

990

991

992

993

994

995

996

997

998

999

1000

1001

1002

63. Paavola, K.J., et al., The Fibronectin-ILT3 Interaction Functions as a Stromal Checkpoint that Suppresses Myeloid Cells. Cancer Immunol Res, 2021. 9(11): p. 12831297.

64. Tomic, S., et al., Reduced Expression of Autophagy Markers and Expansion of Myeloid-Derived Suppressor Cells Correlate With Poor T Cell Response in Severe COVID-19 Patients. Front Immunol, 2021. 12: p. 614599.

65. Fouet, G., et al., Molecular Basis of Complement C1q Collagen-Like Region Interaction with the Immunoglobulin-Like Receptor LAIR-1. Int J Mol Sci, 2021. 22(10).

66. Hadjadj, J., et al., Impaired type I interferon activity and inflammatory responses in severe COVID-19 patients. Science, 2020. 369(6504): p. 718-724.

67. Cizmecioglu, A., et al., Apoptosis-induced T-cell lymphopenia is related to COVID-19 severity. J Med Virol, 2021. 93(5): p. 2867-2874.

68. Feng, Z., et al., The Novel Severe Acute Respiratory Syndrome Coronavirus 2 (SARSCoV-2) Directly Decimates Human Spleens and Lymph Nodes. medRxiv, 2020: p. 2020.03.27.20045427.

69. Sethi, S., et al., A proposal for standardized grading of chronic changes in native kidney biopsy specimens. Kidney Int, 2017. 91(4): p. 787-789.

70. Ishak, K., et al., Histological grading and staging of chronic hepatitis. J Hepatol, 1995. 22(6): p. 696-9.

71. Gorkiewicz, G., et al., Species-specific identification of campylobacters by partial $16 \mathrm{~S}$ rRNA gene sequencing. J Clin Microbiol, 2003. 41(6): p. 2537-46.

72. Corman, V.M., et al., Detection of 2019 novel coronavirus (2019-nCoV) by real-time RT-PCR. Euro Surveill, 2020. 25(3).

73. Hadfield, J., et al., Nextstrain: real-time tracking of pathogen evolution. Bioinformatics, 2018. 34(23): p. 4121-4123.

74. Sagulenko, P., V. Puller, and R.A. Neher, TreeTime: Maximum-likelihood phylodynamic analysis. Virus Evol, 2018. 4(1): p. vex042.

75. Dobin, A., et al., STAR: ultrafast universal RNA-seq aligner. Bioinformatics, 2013. 29(1): p. 15-21.

76. Langmead, B. and S.L. Salzberg, Fast gapped-read alignment with Bowtie 2. Nat Methods, 2012. 9(4): p. 357-9.

77. Robinson, M.D., D.J. McCarthy, and G.K. Smyth, edgeR: a Bioconductor package for differential expression analysis of digital gene expression data. Bioinformatics, 2010. 26(1): p. 139-40.

78. Subramanian, A., et al., Gene set enrichment analysis: a knowledge-based approach for interpreting genome-wide expression profiles. Proc Natl Acad Sci U S A, 2005. 102(43): p. 15545-50.

79. Qi, C., et al., SCovid: single-cell atlases for exposing molecular characteristics of COVID-19 across 10 human tissues. Nucleic Acids Res, 2022. 50(D1): p. D867-D874.

80. Segata, N., et al., Metagenomic microbial community profiling using unique cladespecific marker genes. Nat Methods, 2012. 9(8): p. 811-4.

81. Kostic, A.D., et al., PathSeq: software to identify or discover microbes by deep sequencing of human tissue. Nat Biotechnol, 2011. 29(5): p. 393-6.

82. Bolyen, E., et al., Reproducible, interactive, scalable and extensible microbiome data science using QIIME 2. Nat Biotechnol, 2019. 37(8): p. 852-857.

83. Callahan, B.J., et al., DADA2: High-resolution sample inference from Illumina amplicon data. Nat Methods, 2016. 13(7): p. 581-3. 
medRxiv preprint doi: https://doi.org/10.1101/2022.02.18.22270995; this version posted February 19, 2022. The copyright holder for this preprint (which was not certified by peer review) is the author/funder, who has granted medRxiv a license to display the preprint in It is made available under a CC-BY-ND 4.0 International license.

1003

1004

1005

1006

1007

\section{Supplemental Figures}

1008

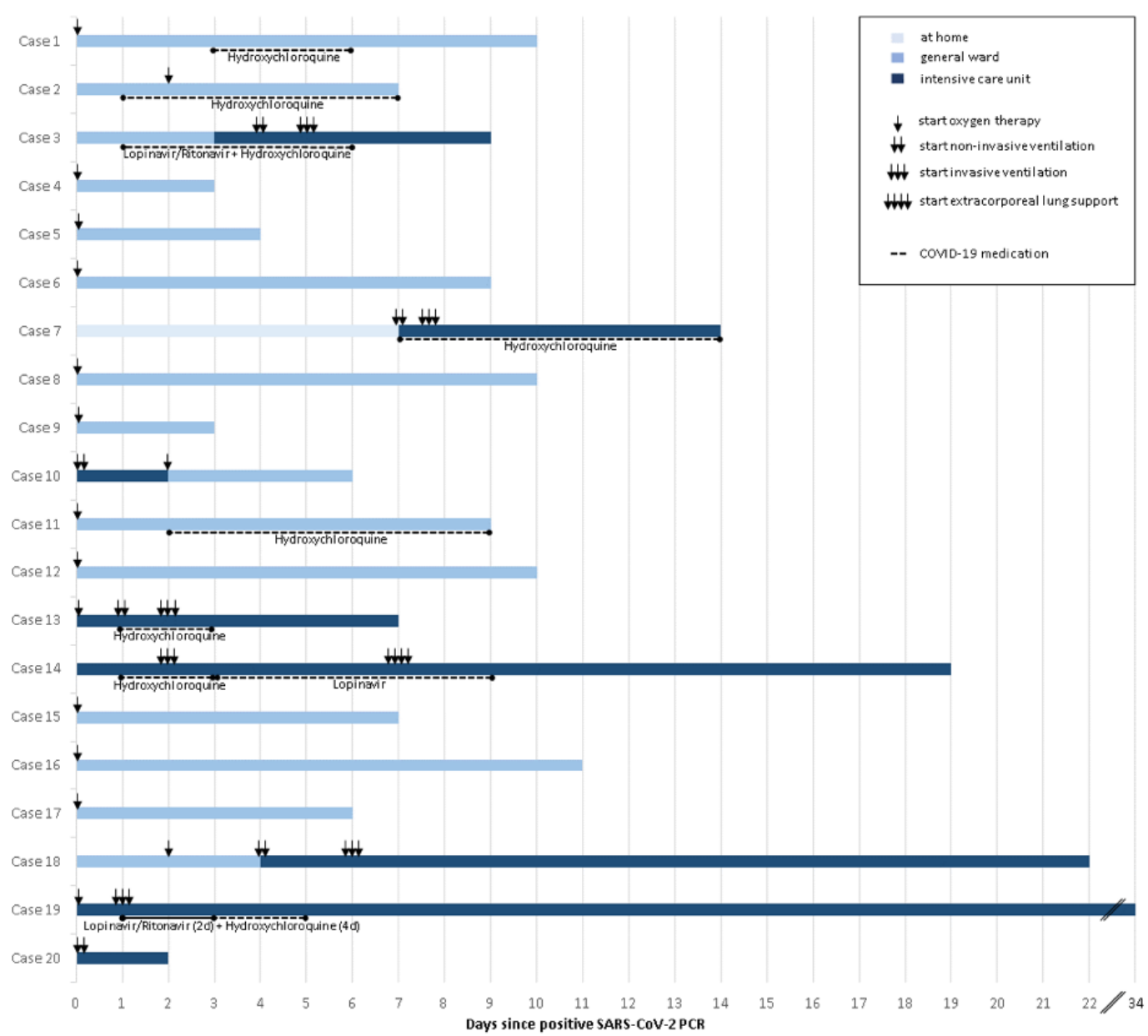

1009 Figure S1. Clinical courses of covid-19 cases. X-axis specifies interval from SARS-CoV-2 positive PCR. Treatment in the general ward and/or intensive care unit is shown. Start of ventilation 1012 1013
84. Segata, N., et al., Metagenomic biomarker discovery and explanation. Genome Biol, 2011. 12(6): p. R60. 
medRxiv preprint doi: https://doi.org/10.1101/2022.02.18.22270995; this version posted February 19, 2022. The copyright holder for this preprint (which was not certified by peer review) is the author/funder, who has granted medRxiv a license to display the preprint in perpetuity.
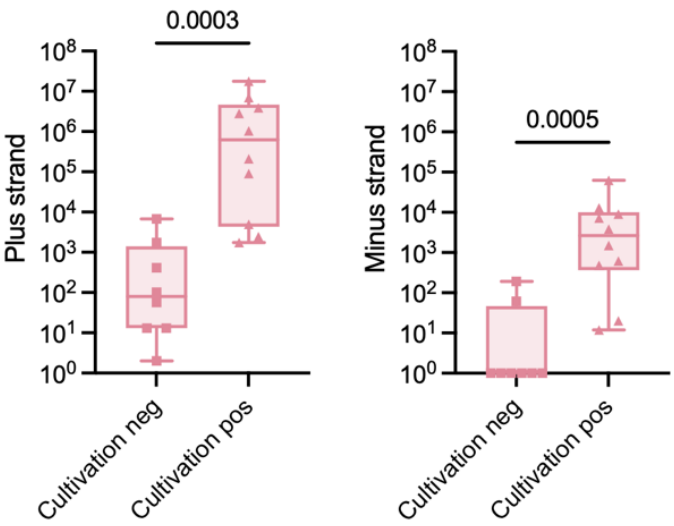

Figure S2. Relation of SARS-CoV-2 cultivability and transcript levels determined by RNAseq (Mann-Whitney test).
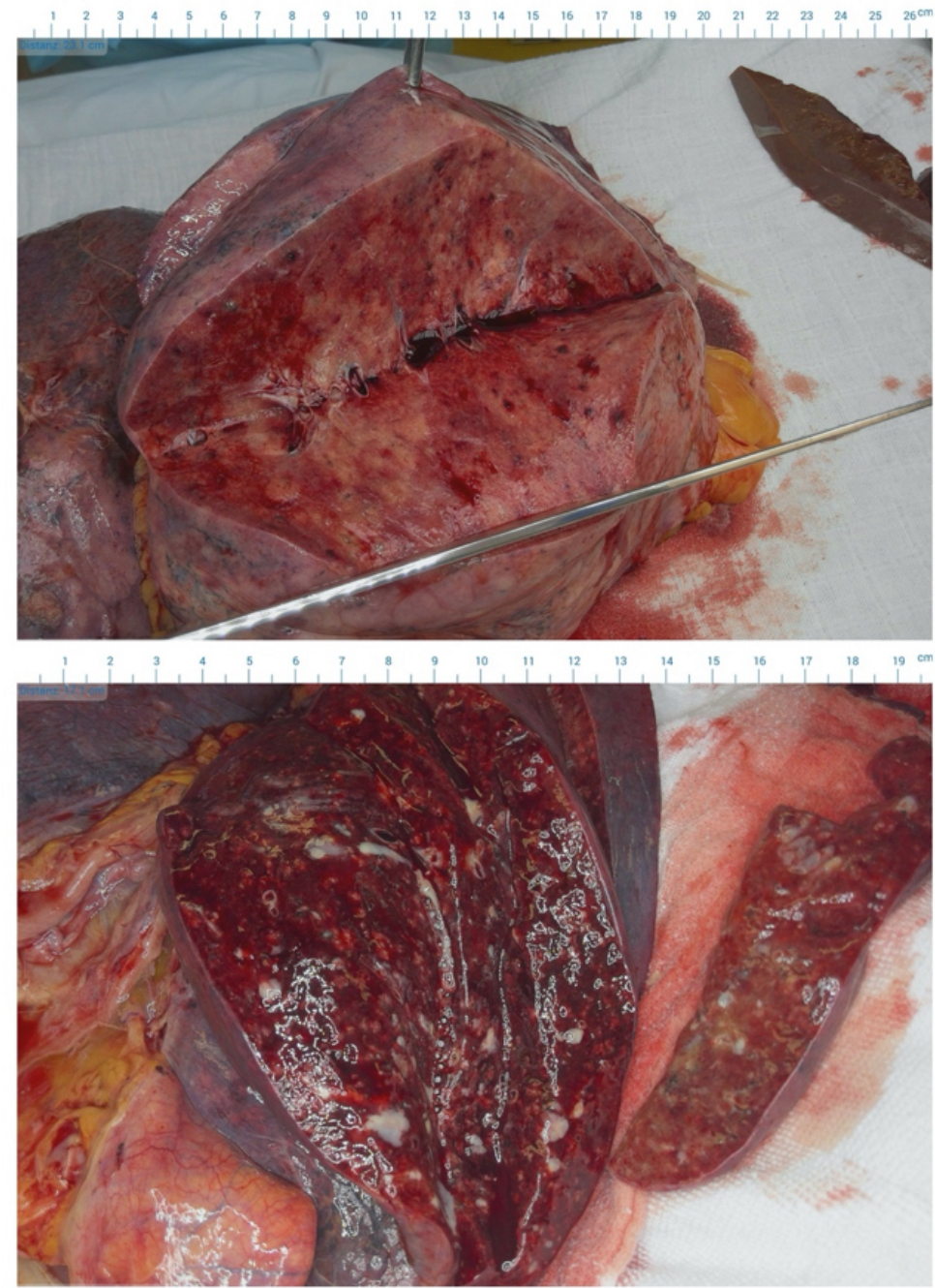

Figure S3. Gross pathology representation of lung. (Top) Section through a lobe with DAD. The lung parenchyma is inhomogeneously colored and consolidated. (Bottom) A case with bacterial superinfection shows pus in bronchial lumina and on the cut surface of the lung. 


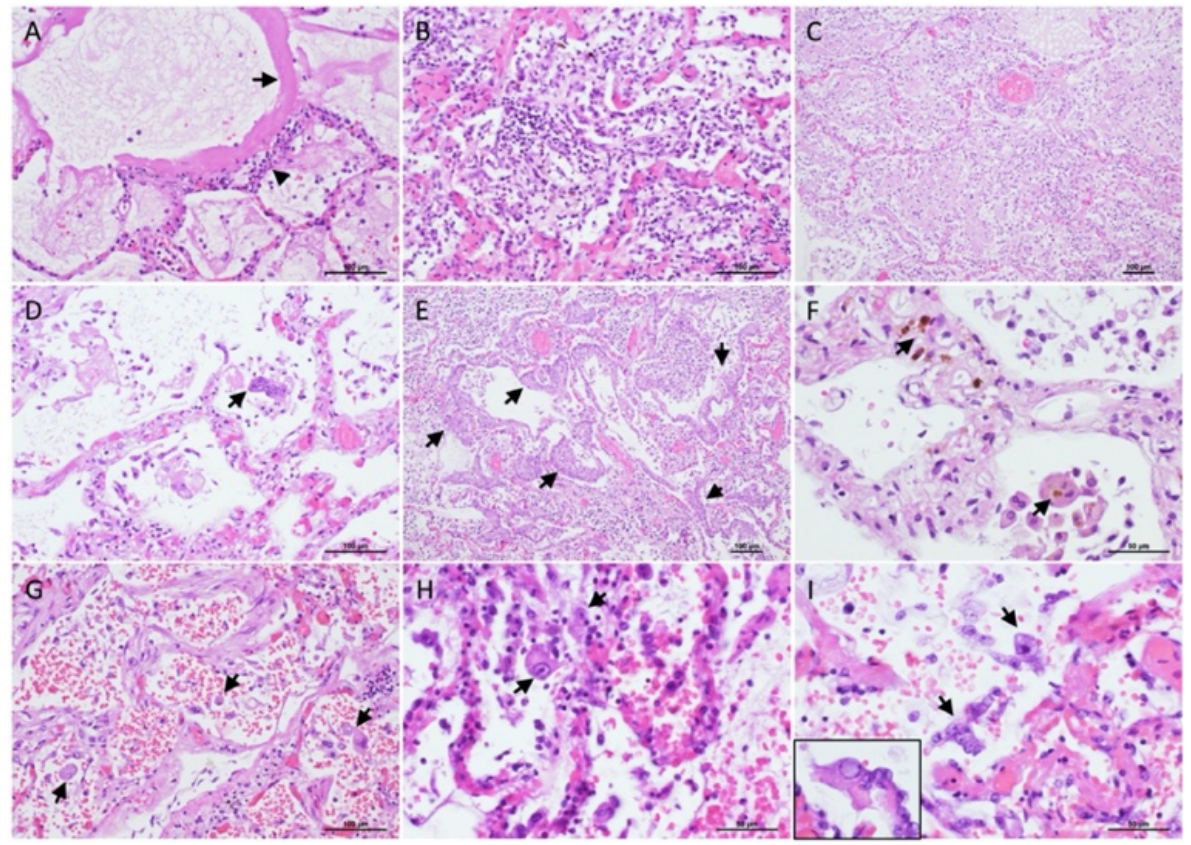

Figure S4. Histological representation of DAD in covid-19. (A) Exudative DAD with hyaline membranes (arrows) and lymphocytic interstitial infiltrates in alveolar septa (arrowhead). (B, C) Organizing DAD with intra-alveolar fibro-cellular infiltrates. (D) Multinucleated syncytial pneumocytes in organizing DAD (arrow). (E) Squamous metaplasia in organizing DAD (arrows). (F) Hemosiderin in alveolar septa and alveolar macrophages (arrows). (G-I) Pneumocyte nuclear atypia with macro-nucleoli (arrows; "owl-eye" in H). Atypical pneumocytes are often scaled off the alveolar membrane. In $\mathrm{G}$ also alveolar hemorrhage is evident. Inset in I shows ground-glass nuclear changes in atypical pneumocytes.

1037

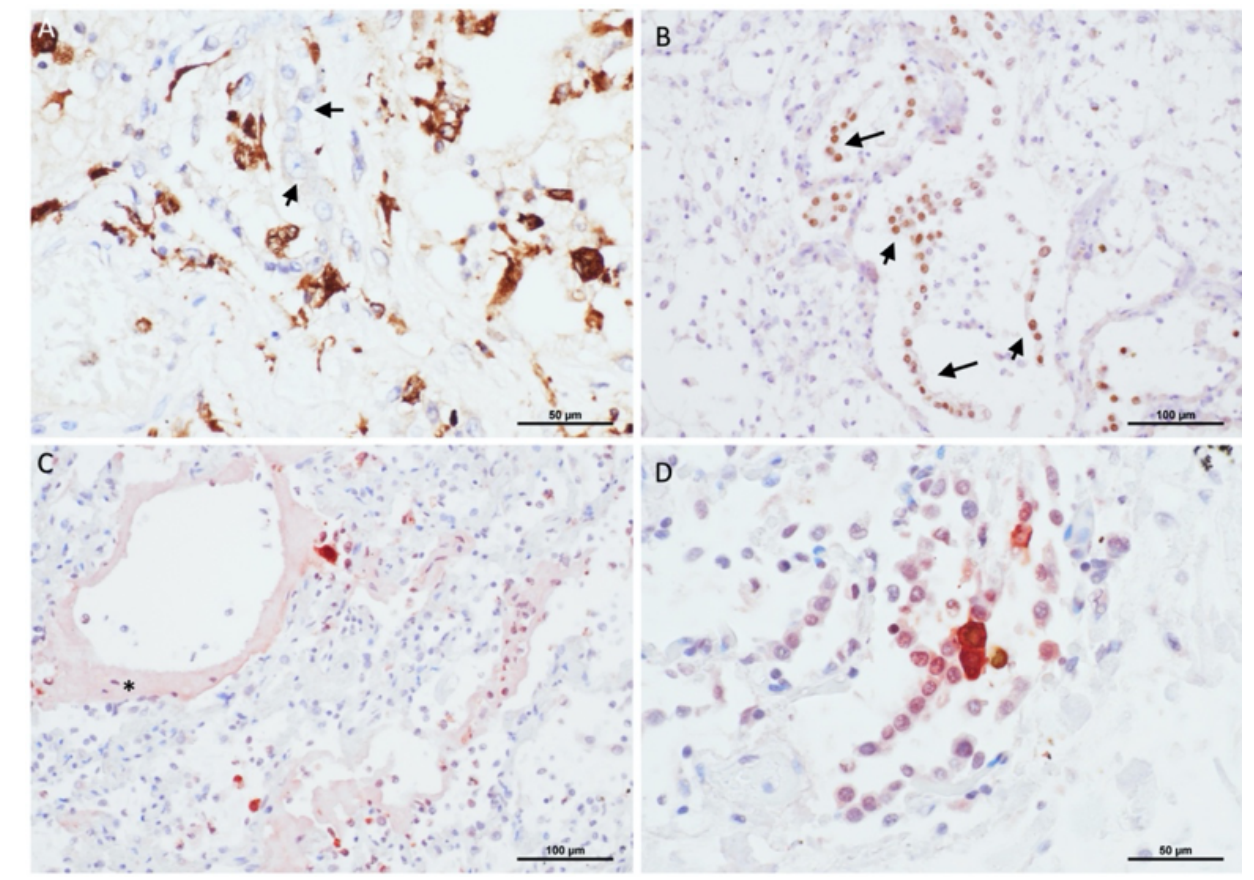

Figure S5. Immunohistochemical analyses of DAD. (A) Macrophage specific CD68 staining. Note the non-stained atypical pneumocytes (arrows). (B) Pneumocytes are scaled-off from the alveolar membrane (pneumocyte specific nuclear TTF-1 staining, arrows). (C, D) SARS-CoV- 
medRxiv preprint doi: https://doi.org/10.1101/2022.02.18.22270995; this version posted February 19, 2022. The copyright holder for this preprint (which was not certified by peer review) is the author/funder, who has granted medRxiv a license to display the preprint in

1044

1045

1046

1047

1048
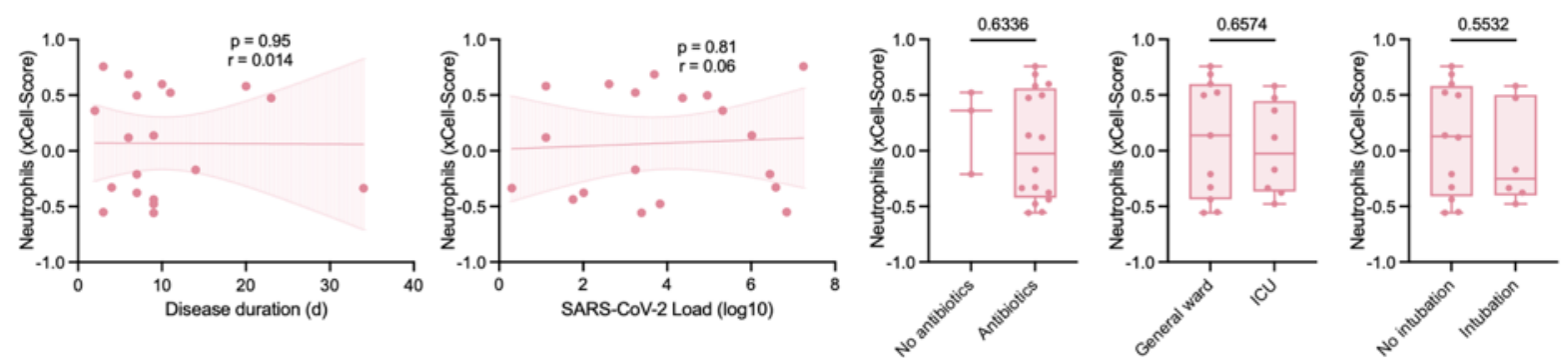

Figure S6. Neutrophils and clinical parameters. Correlation analyses of neutrophil abundance (determined by deconvolution of RNAseq data with xCell) and clinical parameters (Spearman correlation, Mann-Whitney test).
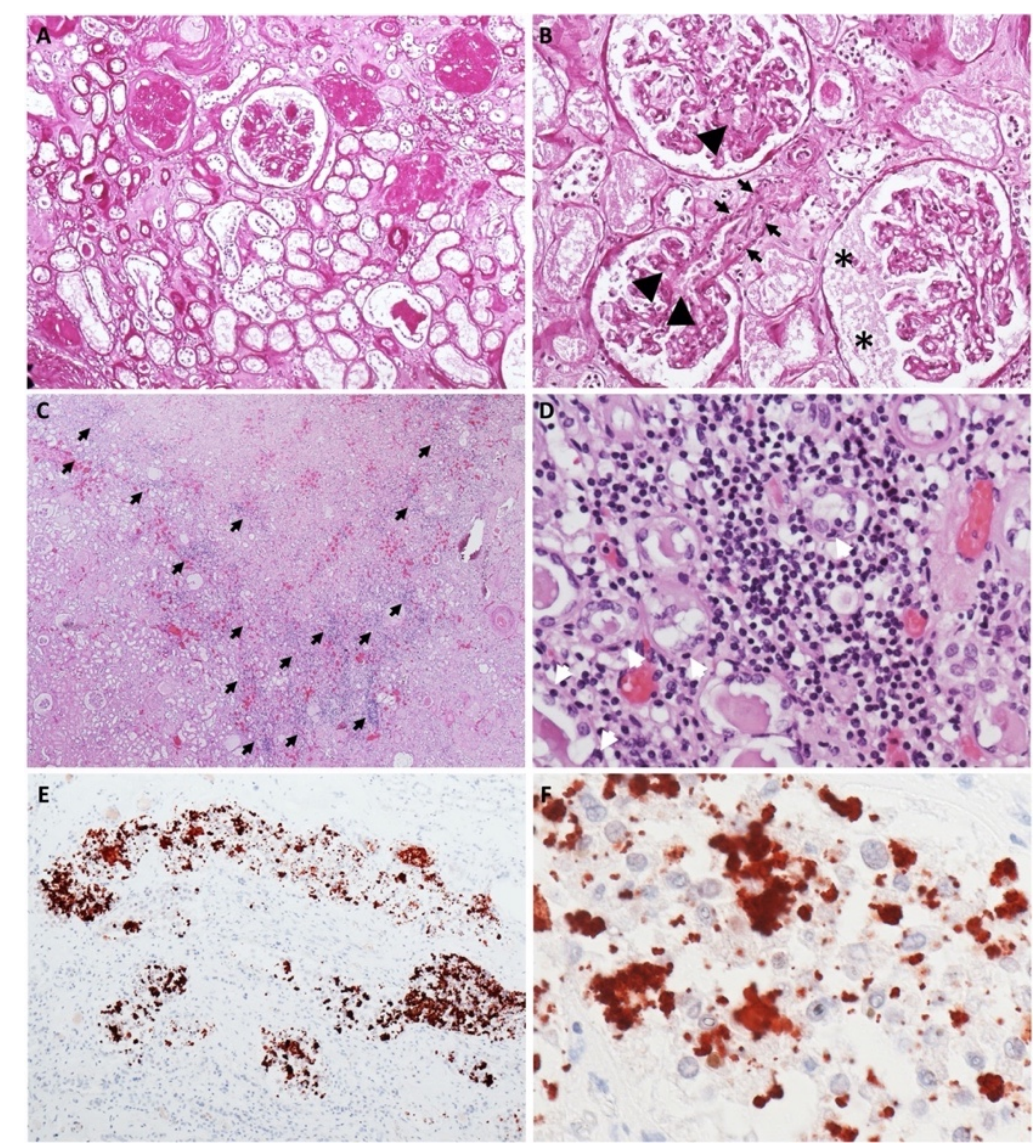

Figure S7 Kidney histopathology. (A) PAS-stained kidney specimen with advanced diffuse and nodular diabetic glomerulosclerosis, advanced parenchymal atrophy and severe arteriolohyalinosis (100-fold). (B) PAS-stained kidney specimen showing segmental obliteration of glomerular capillary loops by fibrin thrombi (arrowheads), endothelitis of a glomerular arteriole (arrows) and accumulation of plasma in Bowman's space (asterisks; 200fold). (C) Overview of an H\&E-stained kidney specimen with diffuse lymphocytic tubulointerstitial nephritis (arrows; 20-fold). (D) H\&E-stained kidney specimen showing severe tubular epithelial changes: loss of brush border, nuclear swelling and cytoplasmic vacuolisation. Note the tubulo-interstitial inflammatory cell infiltrate, mainly consisting of lymphocytes with foci of tubulitis, as characterized by the presence of mononuclear cells on the basolateral aspect of the tubular epithelial cells (400-fold). (E, F) Immunohistochemical detection of SARS-CoV-2 nucleoprotein showing granular staining predominantly in the cytoplasm and occasionally in the nuclei of tubular epithelial cells of large distal tubules (100fold \& 600-fold, respectively). 
medRxiv preprint doi: https://doi.org/10.1101/2022.02.18.22270995; this version posted February 19, 2022. The copyright holder for this preprint (which was not certified by peer review) is the author/funder, who has granted medRxiv a license to display the preprint in
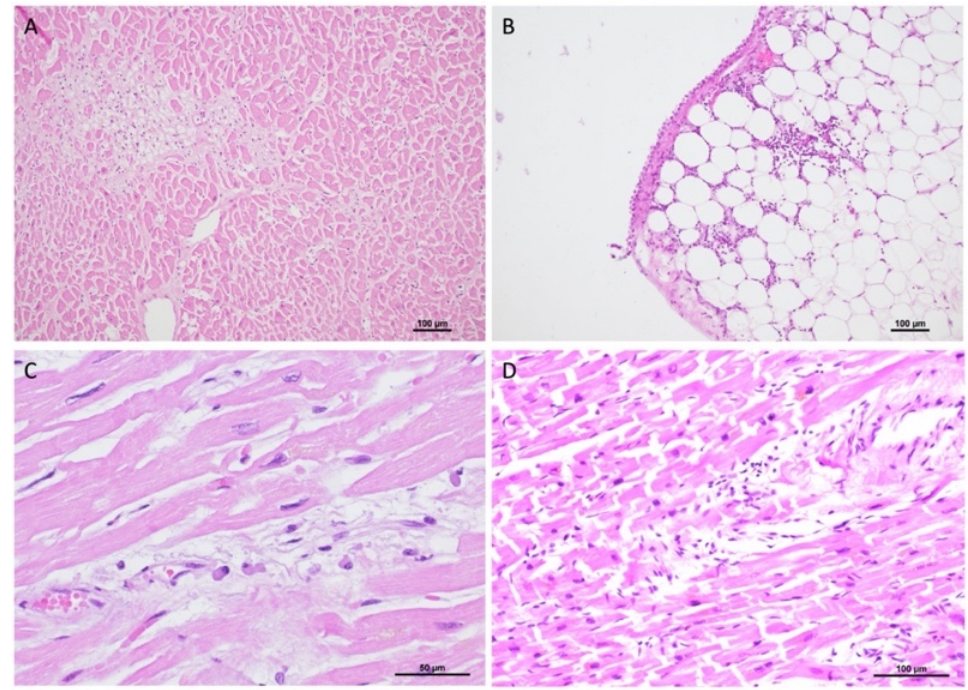

Figure S8. Heart histopathology. (A) Fresh small scar in the myocardium. (B) Sparse subepicardial lymphocytic infiltrate. (C, D) Single plasma cells and lymphocytes in the endomysium around vessels.
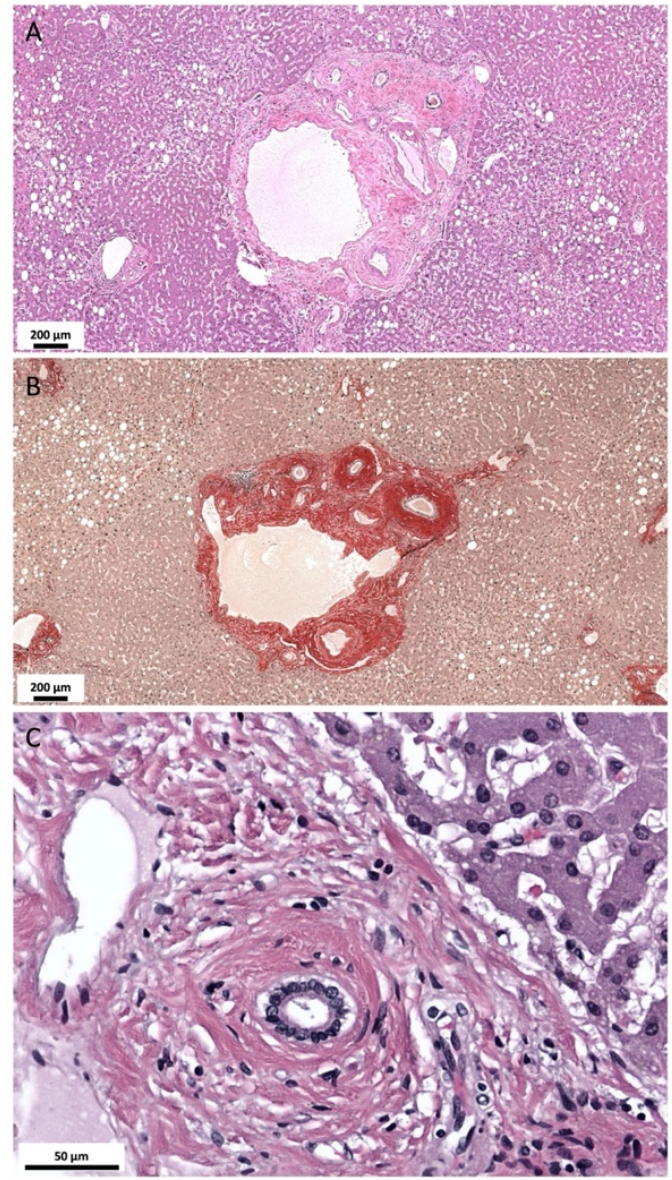

Figure S9. Liver Histopathology. Morphological changes resembling sclerosing cholangitis COVID 19. (A) Preserved lobular architecture. Mild macrovesicular steatosis of the lobular parenchyma. Liver septum with mild lymphocytic infiltrates and septal bile duct adjacent to the A. hepatica branch surrounded by thick layer of condensed collagen fibers (50-fold; hematoxylin \& eosin). (B) Sclerosis is highlighted by the sirius red connective tissue stain (50fold; sirius red). (C) Portal tract with interlobular bile duct and periductal sclerosis. 
medRxiv preprint doi: https://doi.org/10.1101/2022.02.18.22270995; this version posted February 19, 2022. The copyright holder for this preprint (which was not certified by peer review) is the author/funder, who has granted medRxiv a license to display the preprint in perpetuity.

It is made available under a CC-BY-ND 4.0 International license .
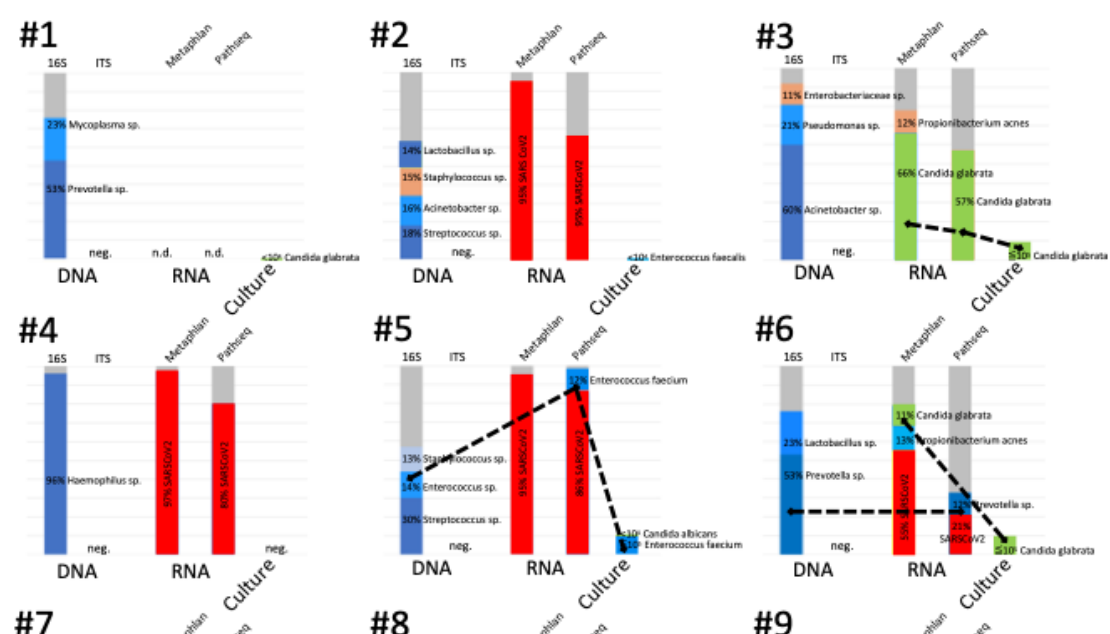

\#7

\#8
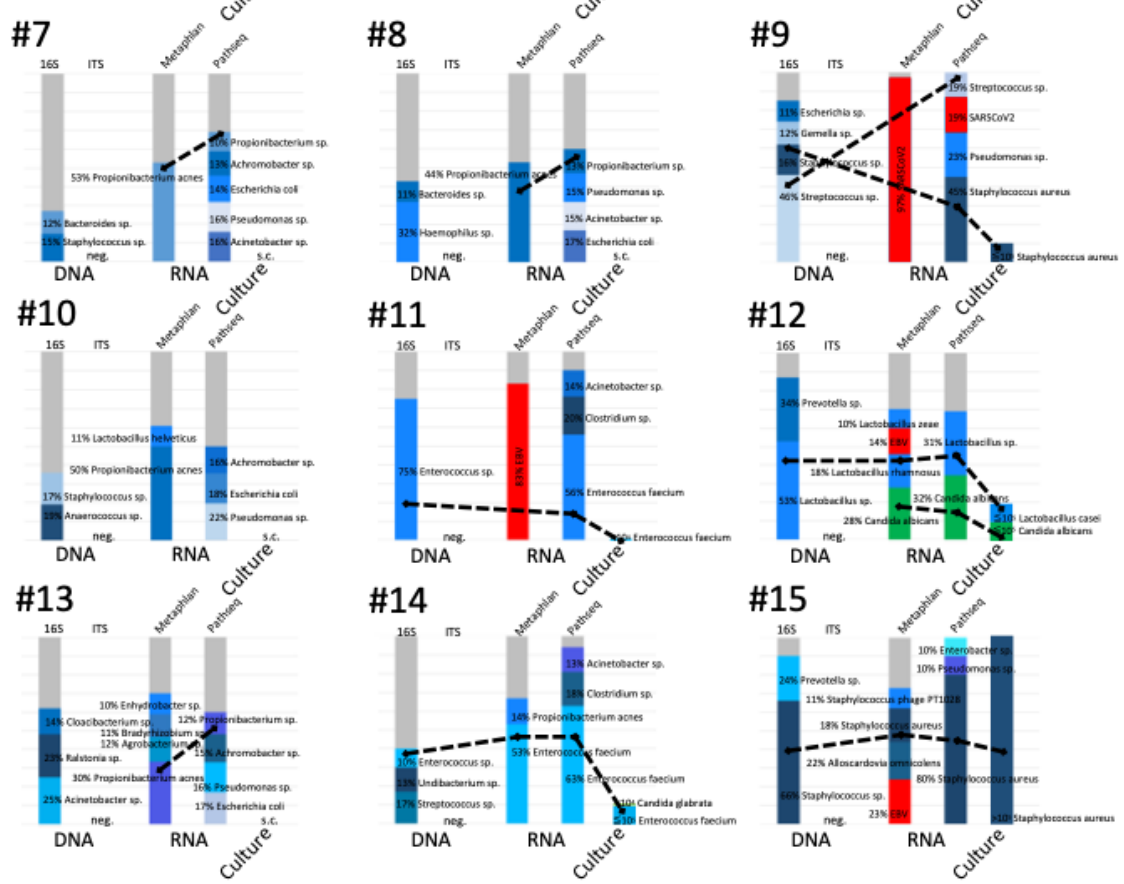

1079
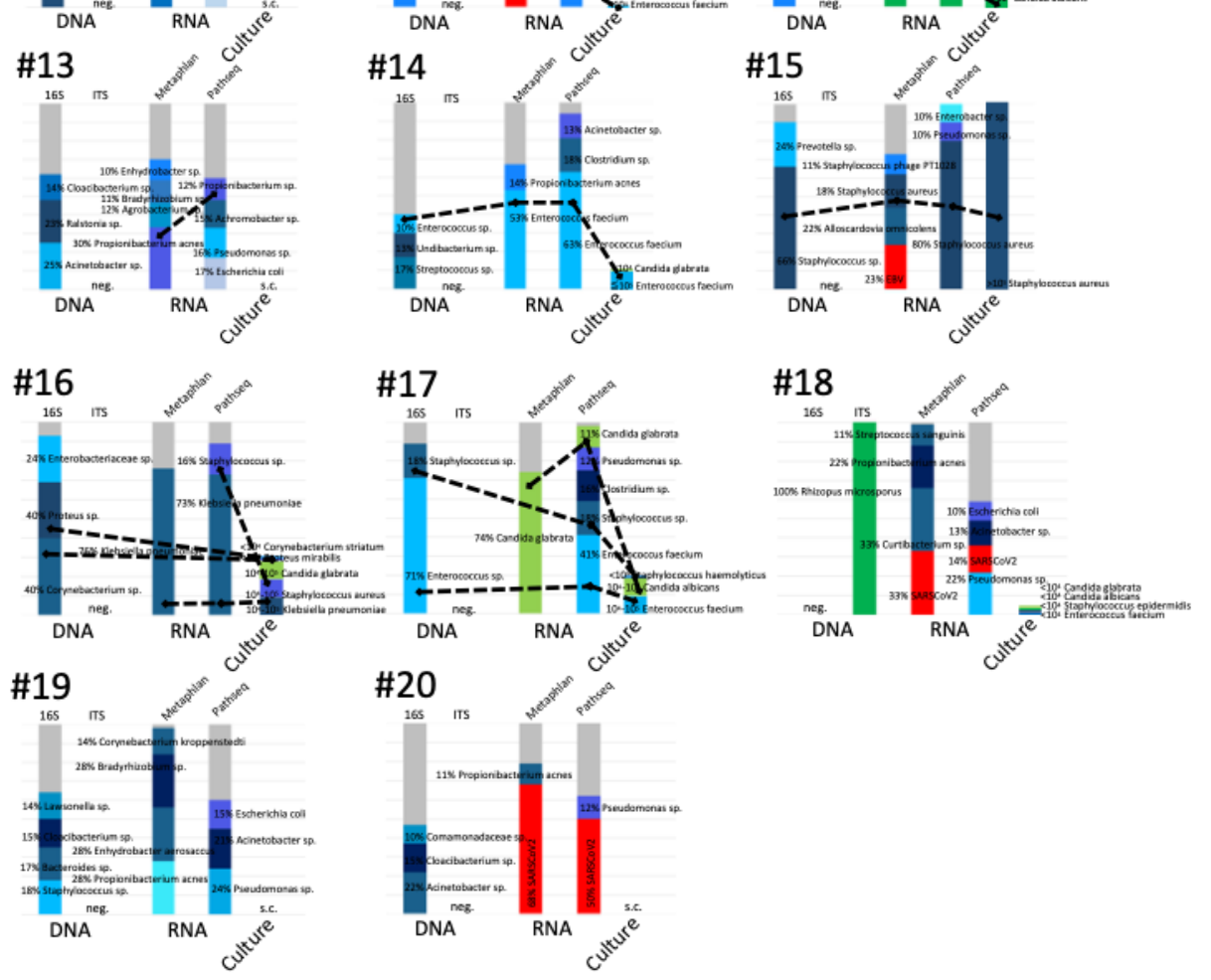

Figure S10. Dominant taxa identified by molecular methods and cultivation in covid-19 lungs. Shown is the relative abundance of $16 \mathrm{~S}$ rRNA gene and ITS sequencing and microbial RNAseq data annotated with Metaphlan or Pathseq pipelines. 
medRxiv preprint doi: https://doi.org/10.1101/2022.02.18.22270995; this version posted February 19, 2022. The copyright holder for this preprint (which was not certified by peer review) is the author/funder, who has granted medRxiv a license to display the preprint in perpetuity.

It is made available under a CC-BY-ND 4.0 International license .

1086
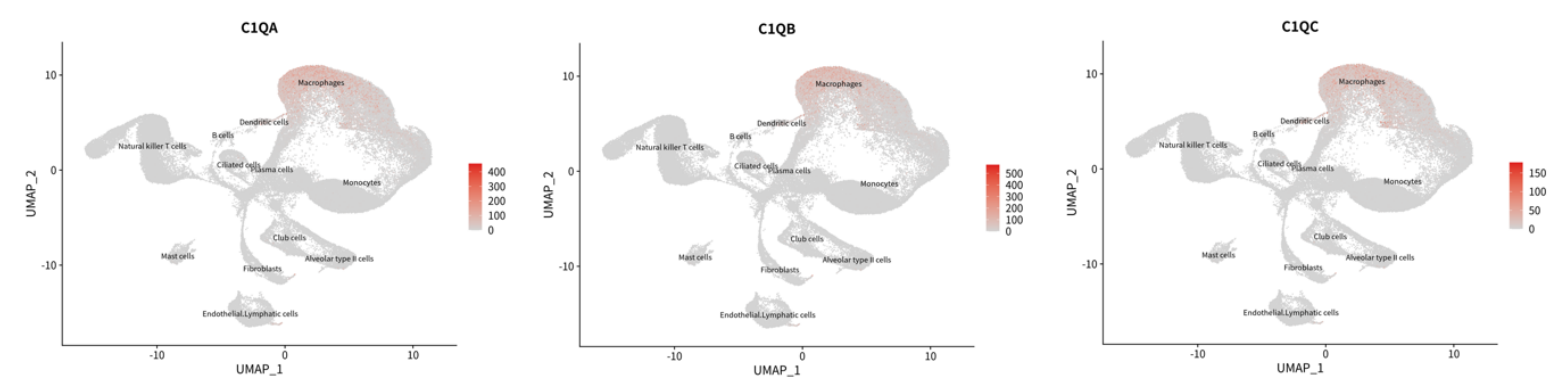

Figure S11. Single cell transcriptomic analysis. $C 1 q A, B$ and $C$ chains are mainly expressed by macrophages. Data derived from Xu et al [31] and analyzed with SCovid single-cell atlas database [79].

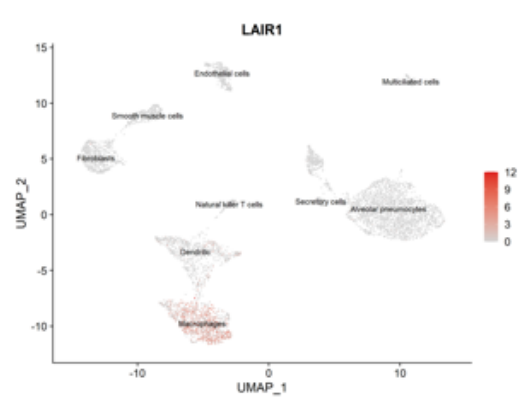

Figure S12. Single cell transcriptomic analysis. $L A I R-1$ is mainly expressed by macrophages. Data derived from Delorey et al [17] and analyzed with SCovid single-cell atlas database [79].
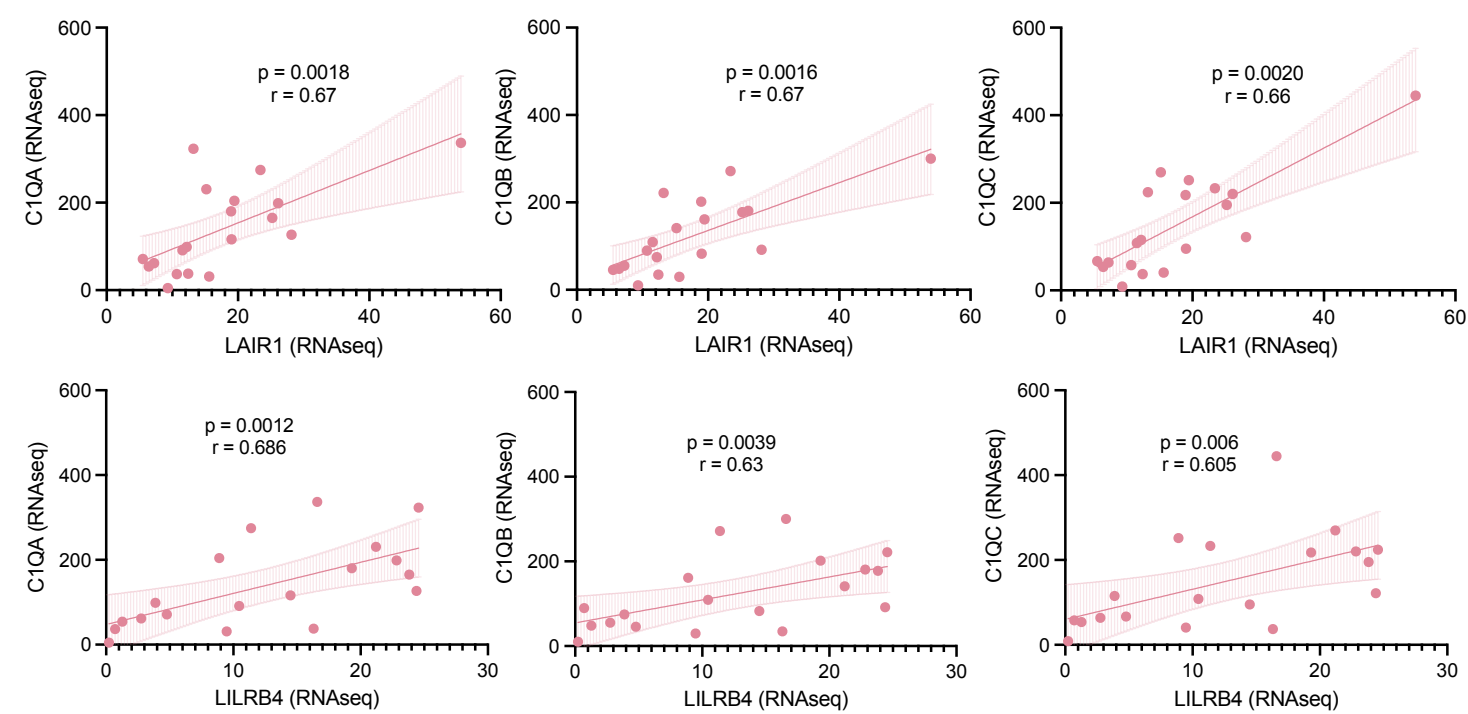

Figure S13. Transcriptomic correlation of C1q, LAIR-1 and LILRB4 from RNAseq. Correlation of C1q chains with LAIR-1 (top) and LILRB4 (bottom; Spearman correlation). 
medRxiv preprint doi: https://doi.org/10.1101/2022.02.18.22270995; this version posted February 19, 2022. The copyright holder for this preprint (which was not certified by peer review) is the author/funder, who has granted medRxiv a license to display the preprint in perpetuity.

It is made available under a CC-BY-ND 4.0 International license .

1103

1104

1105

1106

1107

1108

1109

1110

1111

1112

1113
Controls

$\begin{array}{llll} & 21222324 & 25262728 & 293031 \\ \text { TGF- } \beta & - & \\ \text { GAPDH } & & \\ & & \end{array}$

COVID-19

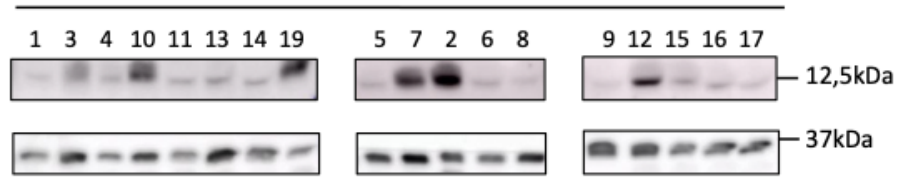

Figure S14. TGF beta $1(12.5 \mathrm{kDa})$ western blots in covid-19 lung tissues and controls (reference human GAPDH).
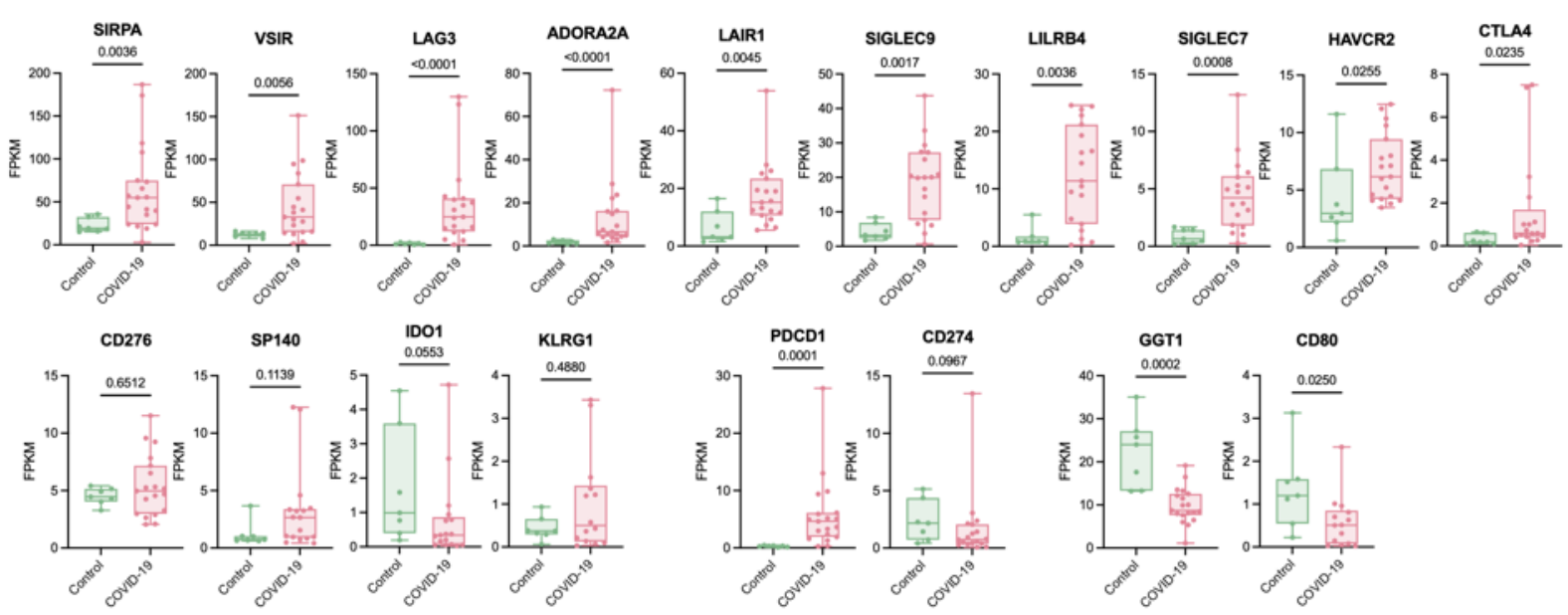

Figure S15. Inhibitory immune checkpoints in covid-19 and controls from RNAseq. Immune checkpoint inhibitor expression in covid-19 compared to controls (Mann-Whitney test). 
medRxiv preprint doi: https://doi.org/10.1101/2022.02.18.22270995; this version posted February 19, 2022. The copyright holder for this preprint (which was not certified by peer review) is the author/funder, who has granted medRxiv a license to display the preprint in perpetuity.

It is made available under a CC-BY-ND 4.0 International license .

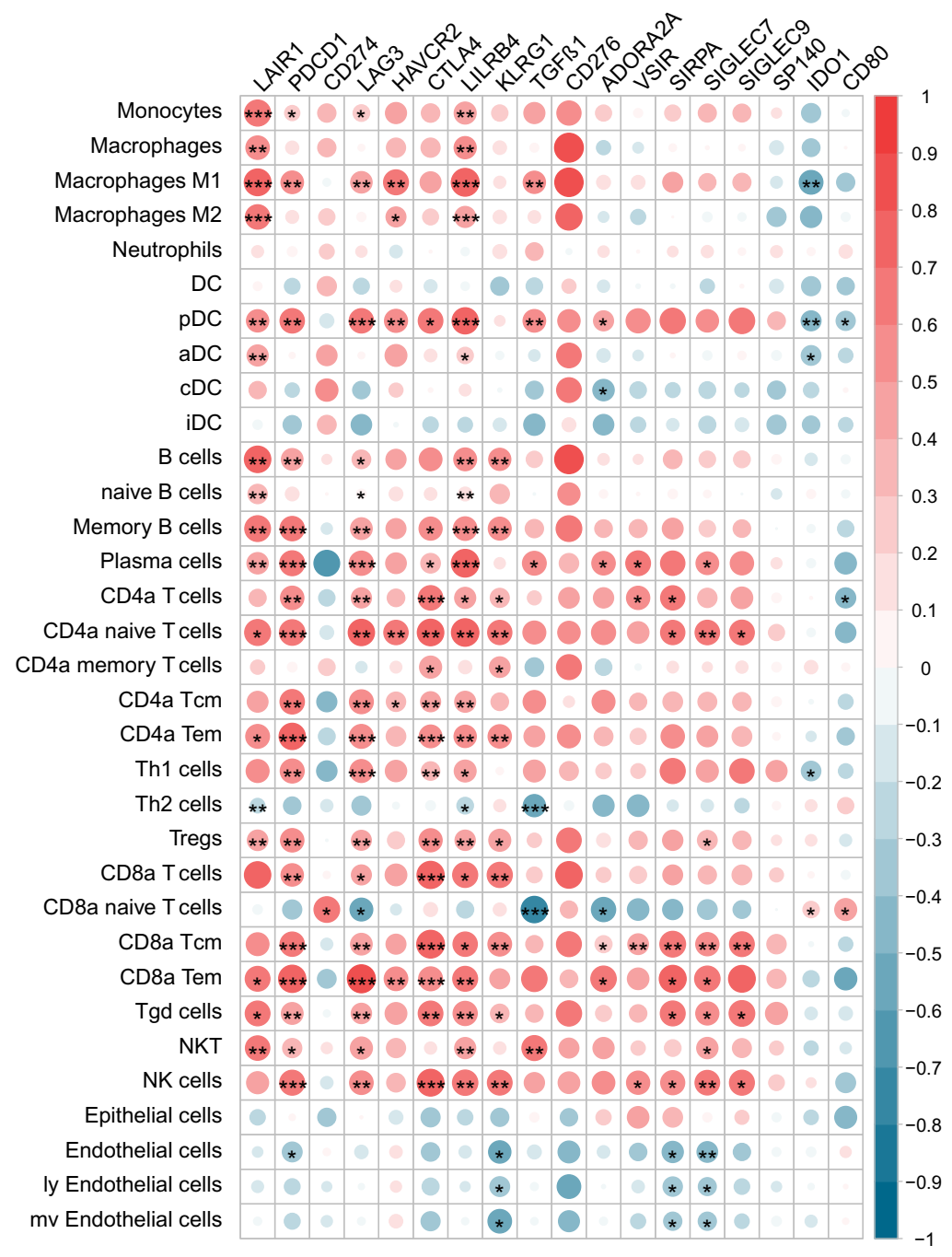

Figure S16. Inhibitory immune checkpoints and cell types from RNAseq data. Correlation analysis of immune-checkpoints and cell types derived from xCell analysis (Spearman

1117 correlation; $\left.p^{*}<0.05, p^{* * *}<0.001\right)$. 